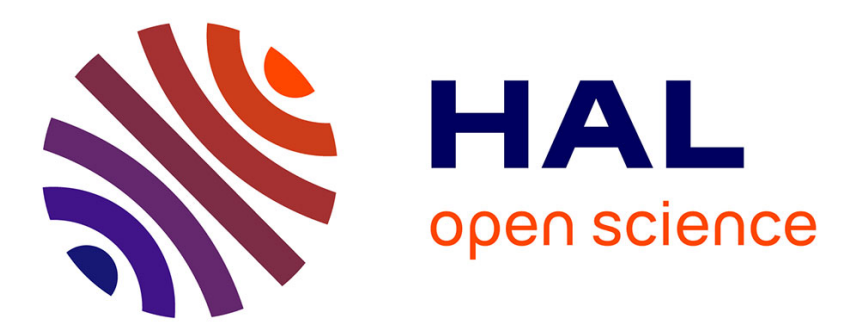

\title{
Transpressional tectonics and stream terraces of the Gobi-Altay, Mongolia
}

\author{
R. Vassallo, J.F. Ritz, Regis Braucher, Marc Jolivet, S. Carretier, C.
} Larroque, Alain Chauvet, Christian Sue, M. Todbileg, D. Bourles, et al.

\section{- To cite this version:}

R. Vassallo, J.F. Ritz, Regis Braucher, Marc Jolivet, S. Carretier, et al.. Transpressional tectonics and stream terraces of the Gobi-Altay, Mongolia. Tectonics, 2007, 26 (5), pp.TC5013. 10.1029/2006TC002081. hal-00323558v2

\section{HAL Id: hal-00323558 \\ https://hal.science/hal-00323558v2}

Submitted on 16 Mar 2017

HAL is a multi-disciplinary open access archive for the deposit and dissemination of scientific research documents, whether they are published or not. The documents may come from teaching and research institutions in France or abroad, or from public or private research centers.
L'archive ouverte pluridisciplinaire HAL, est destinée au dépôt et à la diffusion de documents scientifiques de niveau recherche, publiés ou non, émanant des établissements d'enseignement et de recherche français ou étrangers, des laboratoires publics ou privés. 


\title{
Transpressional tectonics and stream terraces of the Gobi-Altay, Mongolia
}

\author{
R. Vassallo, ${ }^{1}$ J.-F. Ritz, ${ }^{1}$ R. Braucher, ${ }^{2}$ M. Jolivet, ${ }^{1}$ S. Carretier ${ }^{3}$ C. Larroque, ${ }^{4}$ \\ A. Chauvet, ${ }^{1}$ C. Sue,${ }^{5}$ M. Todbileg, ${ }^{6}$ D. Bourlès, ${ }^{2}$ A. Arzhannikova, ${ }^{7}$ and S. Arzhannikov ${ }^{7}$
}

Received 14 November 2006; revised 10 April 2007; accepted 25 June 2007; published 9 October 2007.

[1] We studied the patterns, rates and evolution of fluvial terraces and fault system during the building process of an intracontinental transpressional mountain in the Gobi-Altay (Mongolia). By analyzing incisions and offsets of fluvial terraces and alluvial fans, we show that the massif has grown by outward migration of thrust faults through time. On the northern flank, the present bounding thrust fault began its activity $\sim 600 \mathrm{ka}$ ago, while a more internal sub-parallel fault was still active until $\sim 200-100 \mathrm{ka}$. Vertical offset of an alluvial fan abandoned $\sim 100 \mathrm{ka}$ ago allows an estimate of $0.1 \mathrm{~mm} / \mathrm{yr}$ Upper Pleistocene - Holocene uplift rate. The morphology of the catchment-piedmont system strongly suggests a periodical formation of the alluvial surfaces, controlled by the climatic pulses, at the beginning of the wet interglacial periods. The abandonment of the alluvial terraces lags by several thousand years the abandonment of the alluvial fans, showing a diachronous incision propagating upstream. The incision rate deduced from the different elevations of straths exceeds of one order of magnitude the rock uplift rate. This excess is mostly due to ongoing drainage network growth at the core of the massif, and incision due to alluvial apron entrenchment near the outlet. This implies that fluvial response is mainly controlled by drainage growth, interaction with piedmont and cyclic climatic variations, rather than by rock uplift. Citation: Vassallo, R., et al. (2007), Transpressional tectonics and stream terraces of the Gobi-Altay, Mongolia, Tectonics, 26, TC5013, doi:10.1029/2006TC002081.

\section{Introduction}

[2] Mountain building process within transpressional mountain systems often involves massifs developing within

\footnotetext{
${ }^{1}$ Laboratoire Géosciences Montpellier, Université Montpellier II, France.

${ }^{2}$ CEREGE, Aix-en-Provence, France.

${ }^{3}$ LMTG, Toulouse, France.

${ }^{4}$ Géosciences Azur, Sophia-Antipolis, Valbonne, France.

${ }^{5}$ Département de Géologie, Université de Neuchatel, Switzerland.

${ }^{6}$ Mongolian University of Science and Technology, Ulaan Baatar, Mongolia.

${ }^{7}$ Institut of Earth Crust, Irkutsk, Russia.

Copyright 2007 by the American Geophysical Union. 0278-7407/07/2006TC002081
}

restraining bends along strike-slip faults. Such type of mountain ranges has been mainly studied in terms of structures and fault kinematics [e.g., Woodcock and Fischer, 1986; Bayasgalan et al., 1999; Cunningham et al., 2003], but few examples have provided chronological data allowing to understand and quantify the growing process over tens of thousand years in details. For example, it is not clear whether the deformation in a restraining bend occurs on the most external faults alone or whether it is distributed on several faults, or if pre-existing structures control the location of the active faulting during the mountain widening. Establishing the chronology of fault activity should help to better understand the mechanical behavior of a prestructured lithosphere in a transpressive context. Moreover, such a chronology has broad implications concerning the seismic potential of faults within a restraining bend. The studied restraining bend, the Ih Bogd massif, is located along the Bogd fault system in the Gobi-Altay range in Mongolia (Figure 1). It has been the focus of several morphotectonic studies, because the geomorphic markers are exceptionally preserved in this region, and because a 8.3 Mw earthquake occurred on the Bogd fault in 1957 [e.g., Ritz et al., 1995; Bayasgalan et al., 1999; Carretier et al., 2002; Ritz et al., 2003; Vassallo et al., 2005; Ritz et al., 2006].

[3] In order to document the evolution of faults pattern and rates, we analyze how faults have disturbed the geomorphology at a regional scale, and at fault scarp scale. In particular, we map the faults and the geology in the massif, and we map the fluvial terraces and alluvial fans in a selected catchment-piedmont system. Our basic geomorphic reference surfaces for analyzing incision and fault slip rates are the terrace strath levels and the top of the alluvial fan surfaces, respectively.

[4] The Bitut catchment-piedmont system is the largest of the massif and displays the best-preserved levels of fluvial terraces (Figure 2). Terraces and fans are affected by different faults parallel to the mountain front, and to the main left-lateral strike-slip fault (the Bogd fault). We measure incisions and offsets of these markers using precise topographic GPS leveling and we date them using ${ }^{10} \mathrm{Be}$ exposure dating. This approach allows us to establish the timing of the activity on the different faults in the Bitut valley and fans.

[5] Moreover, the fluvial terraces are preserved enough to reconstruct paleo-river profiles correlated with alluvial fans in the apron. The fluvial terraces are likely the product of a cyclic climate with period of $100 \mathrm{ka}$, characterized by the alternation of long-dry glacial periods and short-wet inter- 


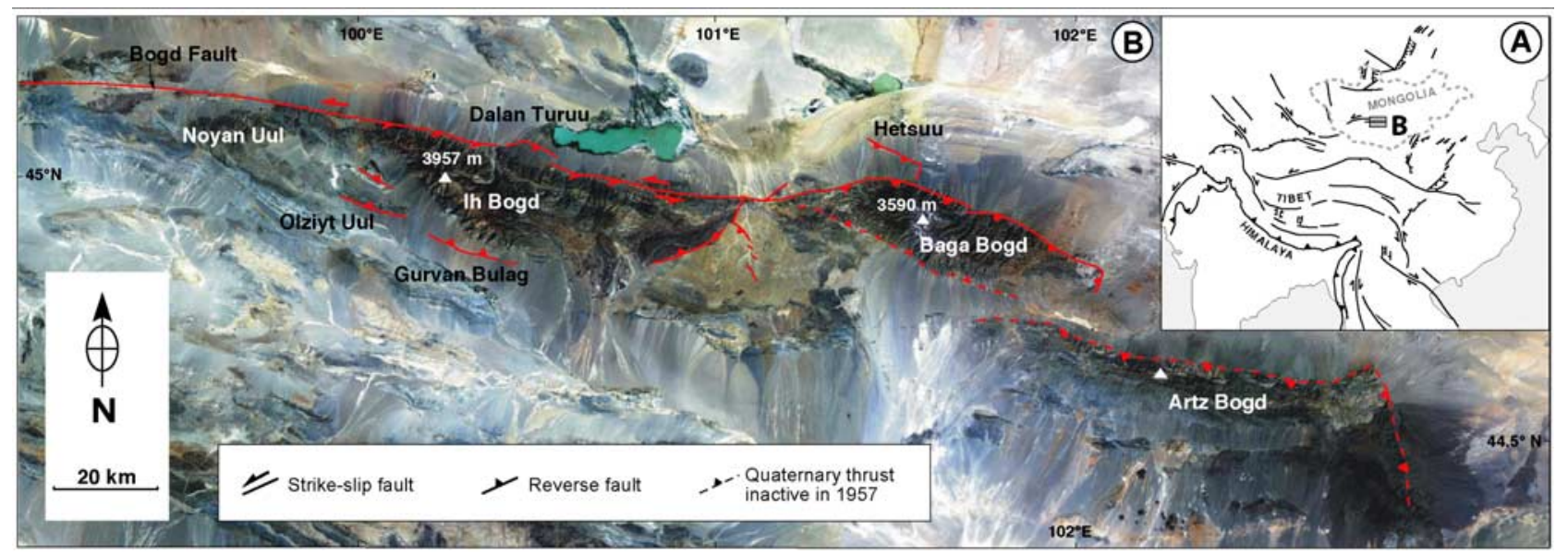

Figure 1. (a) Simplified tectonic map of Central Asia [modified after Molnar and Qidong, 1984]. (b) Sketch map of the Gurvan Bogd system along the left-lateral Bogd strike-slip fault, Gobi-Altay mountain range, Mongolia, on a Landsat image.

glacial periods [Carretier et al., 1998]. The control of global climatic variations on the erosion in the massif is suggested by the morphology of the alluvial piedmont and by the ${ }^{10} \mathrm{Be}$ dating of preserved abandoned alluvial fans [e.g., Ritz et al., 1995; Ritz et al., 2003; Vassallo et al., 2005; Ritz et al., 2006]. Tectonic and climatic landforms offer the possibility of analyzing the complexity of the interactions between tectonics, climate and erosion within the Ih Bogd restraining bend. This allows us to document the geomorphic response of a river in an uplifting massif during several global climatic cycles, which has implications on the tectonic significance of strath terraces, and in the understanding of the mountain building process in intracontinental domain.

\section{Tectonic and Morphologic Setting}

[6] The Ih Bogd massif corresponds to one of the three restraining bends of the Gurvan Bogd fault system, in the eastern part of the Gobi-Altay mountain range, along the left-lateral strike-slip Bogd fault (Figure 1). This fault reactivates ancient structures, and runs along the northern border of the Gurvan Bogd range with a $100^{\circ} \mathrm{E}$ main trend. The fault ruptured lastly with a M 8.3 earthquake in 1957 with a left-lateral-reverse focal mechanism [Florensov and Solonenko, 1965; Baljinnyam et al., 1993; Kurushin et al., 1997].

[7] Local bends along the Bogd fault involve crustal compression and the occurrence of double-verging oblique or reverse faulting on associated segments. The Ih Bogd massif is the highest relief among the restraining bends. Like most of the other restraining bends in the Gobi-Altay and the Altay [Cunningham, 2006], this massif shows an asymmetrical tectonic structure with steeper reverse faults on the northern side than on the southern side (Figure 3). However, as shown by several morphotectonic studies along the bounding thrust faults [Hanks et al., 1997; Carretier, 2000; Ritz et al., 2003; Vassallo et al., 2005; Ritz et al.,
2006], the vertical slip rates on both sides are similar (0.1$0.2 \mathrm{~mm} / \mathrm{yr}$ ). This is consistent with the occurrence of a horizontal flat summit plateau, relict of an ancient erosional surface, which culminates at $\sim 4000 \mathrm{~m}$, standing about $2000 \mathrm{~m}$ above the surrounding piedmonts (Figure 3a). Moreover, the presence of this summit plateau implies that uplift occurred without major tilting or folding at mountain scale. Fission tracks cooling path models suggest that this uplift started between 8 and $2 \mathrm{Ma}$, which makes the longterm Cenozoic uplift rate of the massif lying between 0.25 and $1 \mathrm{~mm} / \mathrm{yr}$ (Vassallo et al., 2007).

[8] The restraining bends within the Gurvan Bogd mountain range are also characterized by the occurrence of frontal thrust faults that affect quaternary alluvial fans and that are called 'forebergs' [Bayasgalan et al., 1999]. These structures on either sides (Dalan Turuu and Hetsuu to the North, Gurvan Bulag and Olziyt Uul to the South), located 1-5 km apart from the main relief, are sub-parallel to the massif boundaries and attest of the widening process of the massif (Figure 4a). The lateral propagation of these faults, observed during the 1957 M8.3 Gobi-Altay earthquake, notably at the western termination of the Gurvan Bulag thrust fault [Bayasgalan et al., 1999], also shows that the relief is growing longitudinally to the Gurvan Bogd fault system (Figure 4b).

[9] The Bitut valley is the most developed drainage basin of the Ih Bogd massif with a surface of about $80 \mathrm{~km}^{2}$ and a length of $18 \mathrm{~km}$ for the main river from the summit plateau $(\sim 4000 \mathrm{~m})$ to the outlet $(1600 \mathrm{~m})$ (Figure 3a). The Bitut river bends toward the middle of its course from a NorthSouth to a $\mathrm{N} 120^{\circ} \mathrm{E}$ direction, becoming parallel to the directions of the geological terranes and of the large-scale crustal fabric. Mass waste processes dominate the topography of the valley, which is thus characterized by average slopes around $30^{\circ}$. Because of the absence of relevant glacial morphologies and deposits, Ih Bogd valleys must be very dry during glacial periods [Carretier et al., 1998; 

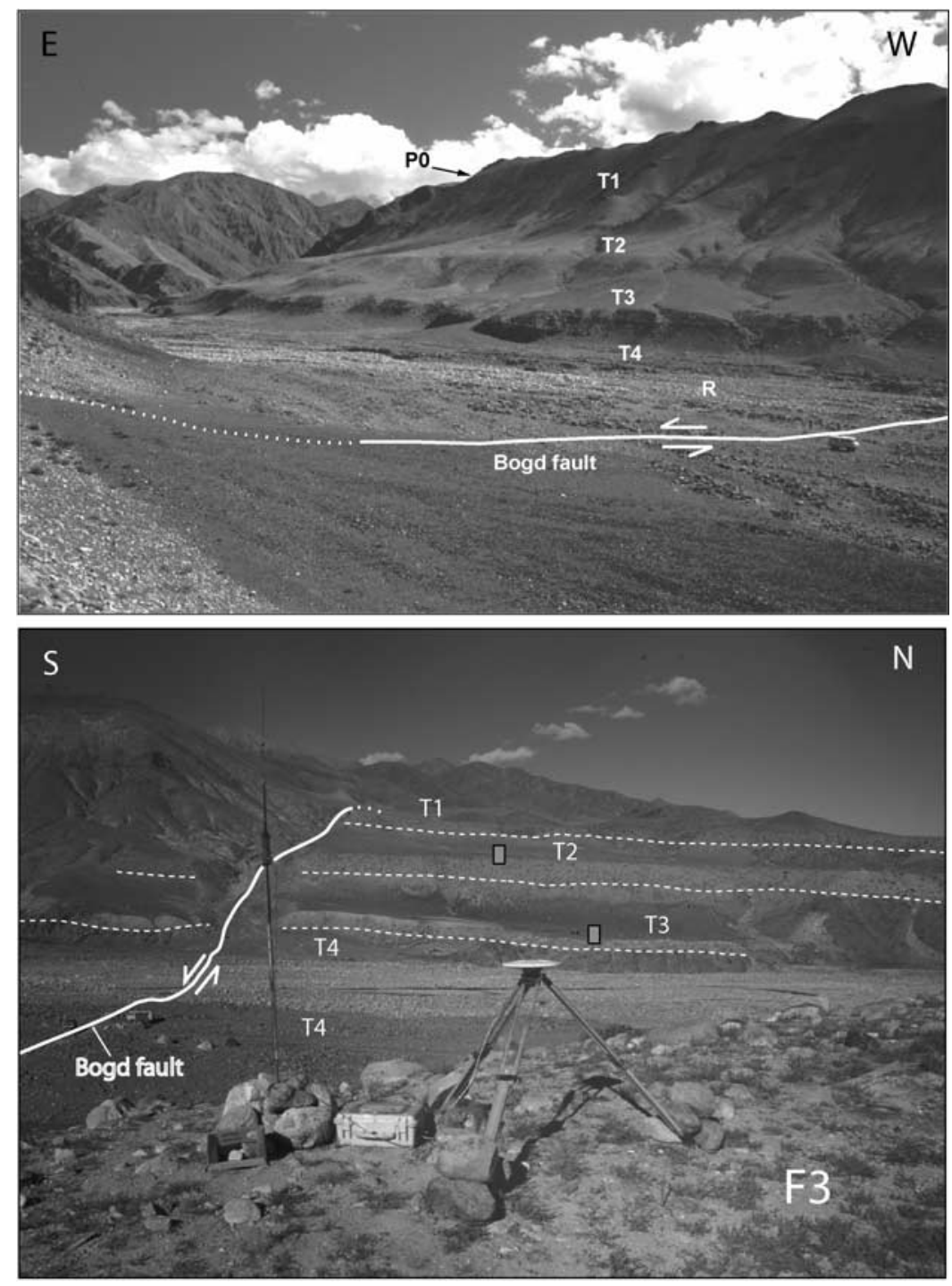

Figure 2. (a) Photograph of the outlet zone of the Bitut valley, showing its four strath terraces (T1 to T4), the present riverbed filled by sediments (R), and the left-lateral Bogd fault (the trace of the fault hidden by the topography is represented in dotted line). An uplifted piedmont (P0) is situated behind the crest as indicated by the arrow (photo by R. Vassallo). (b) Photograph of the strath terraces affected by the left-lateral strike-slip fault segment of the Bogd fault at the outlet of the Bitut valley. In the foreground, the base receiver of the kinematic GPS with its antenna (photo by J-F. Ritz). The two rectangles represent the pit-soils for ${ }^{10} \mathrm{Be}$ profiles. The location of these photos is represented in Figure 5.

Carretier, 2000]. Thus significant bed load transport and fluvial incision can only occur during interglacial periods.

\section{Morphotectonic Analysis}

[10] A general cross section of Ih Bogd massif shows that sub-parallel faults affect the massif, subdividing it into several tectonic units (Figure 3b). These faults correspond to ancient structures [Florensov and Solonenko, 1965], and several of them were reactivated during the late Cenozoic tectonics as suggested by the staircase morphology of the massif (Figure 3). We interpreted this feature as the succession of perched erosional surfaces corresponding to ancient piedmonts located within the footwall of thrust faults. This staircase morphology and the fact that the different stepped surfaces (summit surface and ancient piedmonts) are flat suggest that the Ih Bogd massif corresponds to a pop-up structure, whose uplift is mainly controlled by reverse movement along bounding faults. Moreover, the fact that the summit surface is horizontal along a N-S section (the summit surface is slightly tilted toward the East), and does not show any tracks of ancient transverse drainage, implies that both flanks of the massif are uplifted at the same rate.

[11] We carried out a detailed morphotectonic analysis within the northern part of the Bitut valley - the main catchment basin of the Ih Bogd massif - along which we 

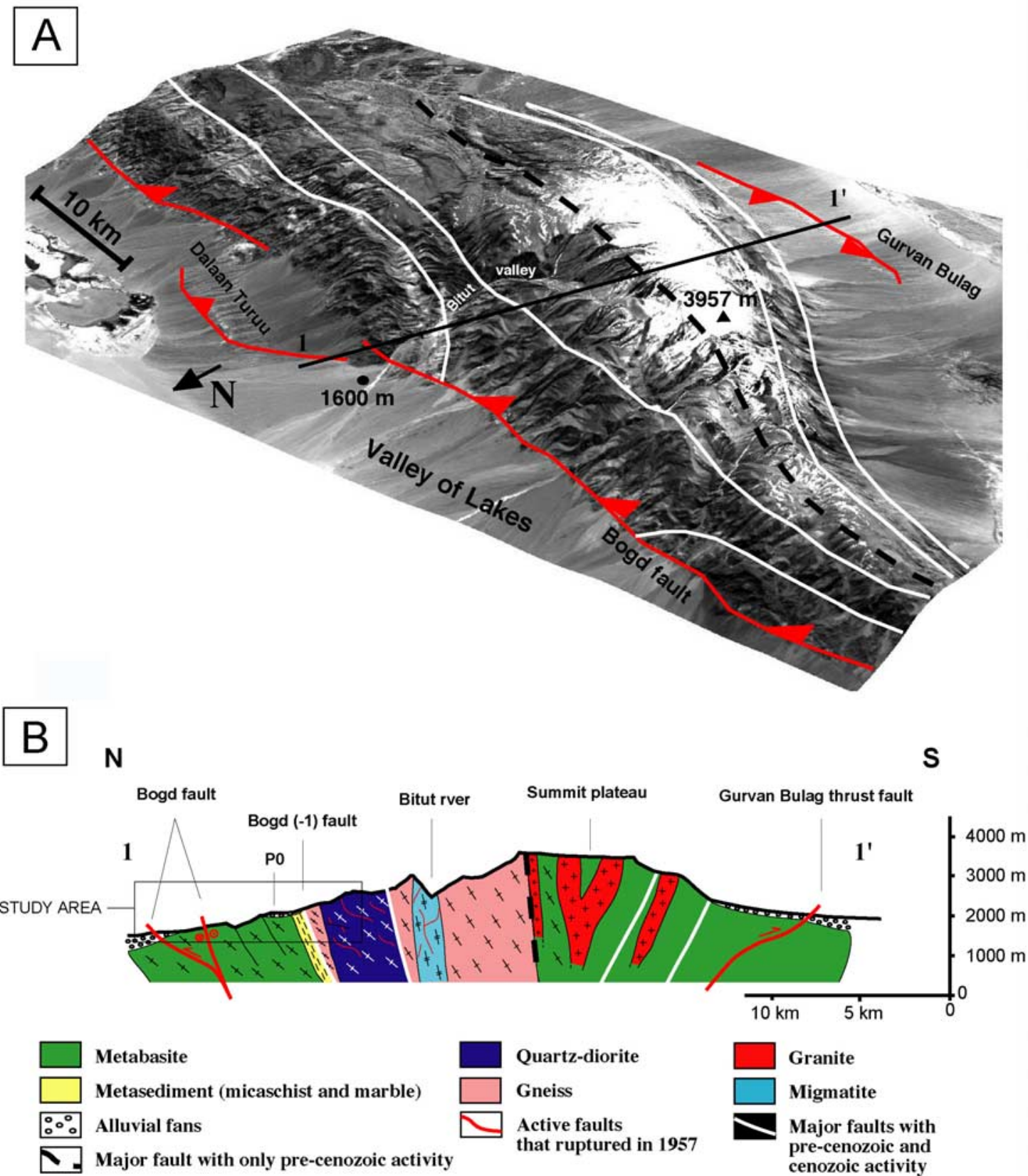

Figure 3. (a) 3D view of the Ih Bogd massif, characterized by an outstanding summit plateau and affected by the transpressive Bogd fault system. (b) Morpho-structural and geological section of the Ih Bogd massif.

observed well-preserved geomorphic markers affected by two faults. We mapped these markers using $1 / 35,000$ aerial photographs and by field survey. The compilation of the topographic data obtained from a kinematics GPS survey allowed us to build up digital elevation models from which we estimated the offsets along the faults, and the differences in height between the different strath terrace levels within the valley.
[12] We now describe fluvial markers in the Bitut valley and their relationships with faults. We begin the description at the outlet of the basin and continue upstream.

\subsection{Outlet Area}

[13] At the outlet of the drainage basin, where the Bogd fault system bounds the massif, we observed four main terraces, $\mathrm{T} 1$ to $\mathrm{T} 4$ ( $\mathrm{T} 4$ is the lowest and therefore the 
$5 \pm 3 \mathrm{Ma}$

$s$
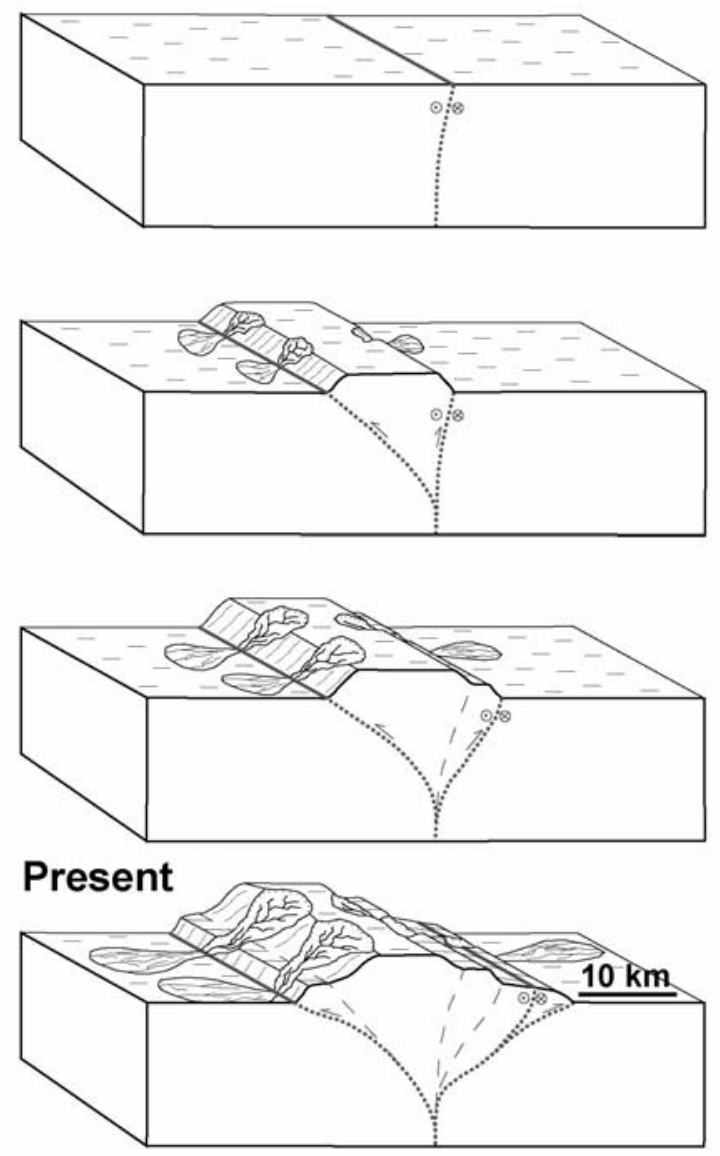

B
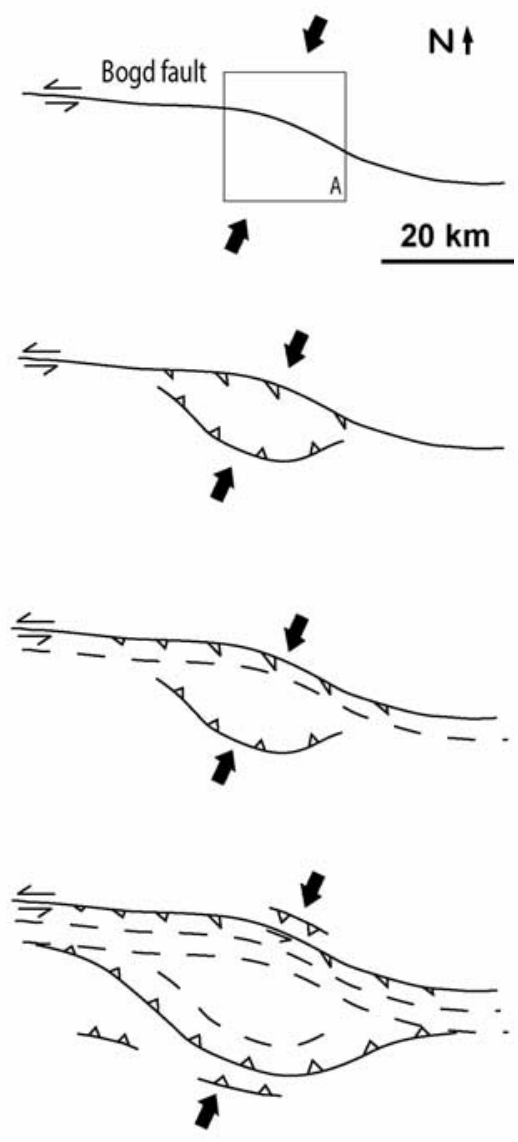

Figure 4. (a) Block diagrams representing the growth of the Ih Bogd massif, from the onset of the uplift to the present stage. This growth is characterized by the successive accretion of crustal blocs, according to the outward migration of the brittle deformation. (b) Corresponding stages in plan view. Note the bidirectional (transversal and longitudinal) growth of the massif.

youngest) (Figures 2 and 5). These terraces are stepped strath terraces covered by alluvial deposits. Downstream the outlet of the Bitut valley, the surface of the two younger terraces (T4 and T3) connects with alluvial fan surfaces (F4 and F3, respectively). The surface of the youngest alluvial fan (F4) is embedded in the older fan (F3) over few kilometers downstream the outlet.

[14] The Bogd fault system shows slip partitioning with some complexity in the distribution of the deformation (Figure 5). The four terraces are affected by a pure leftlateral strike-slip segment (Figures $2 \mathrm{~b}$ and 5), which dies out rapidly to the East after having crossed the valley. Downstream, a complex system of reverse faulting trending roughly parallel to the strike-slip fault affects clearly the alluvial surface F3 (Figure 5). On the 1958 air photographs (taken 6 months after the 1957 earthquake), within the riser of F3 on the east bank of the Bitut river, one of the fault ruptures seems to extend westward across surface F4 over few hundred meters. A topographic profile across surface
F3 allowed estimating a cumulated vertical offset of $10.0 \pm$ $0.5 \mathrm{~m}$ along the frontal reverse fault (Figure 6).

[15] The strike-slip segment does not displace very much the alluvial markers (Figures $2 \mathrm{~b}$ and 5). From a detailed Digital Elevation Model of the fault zone $1 \mathrm{~km}$ to the West of the Bitut valley (Figure 7), we analyzed the displacements of ridges and stream channels. The largest cumulated left-lateral offset that we could estimate is around $20-25 \mathrm{~m}$, while the 1957 co-seismic offset is $3.0 \pm 0.5 \mathrm{~m}$ (Figures 7 and 8). This last value is consistent with the horizontal 1957 co-seismic offset measured by Kurushin et al. [1997] on the same fault segment in the Bitut valley $(3-4 \mathrm{~m})$ and $1 \mathrm{~km}$ westward from this site $(3.9 \pm 1.0 \mathrm{~m})$. Measurements of offset features show that offsets are more or less multiple of $3 \mathrm{~m}$, suggesting that this value is a characteristic slip [see Schwartz and Coppersmith, 1984] on this segment. This is consistent with another segment of the Bogd fault, along the Noyan Uul massif (Figure 1), where a characteristic horizontal slip ( $\sim 5 \mathrm{~m})$ was evidenced [Ritz et al., 2006]. 


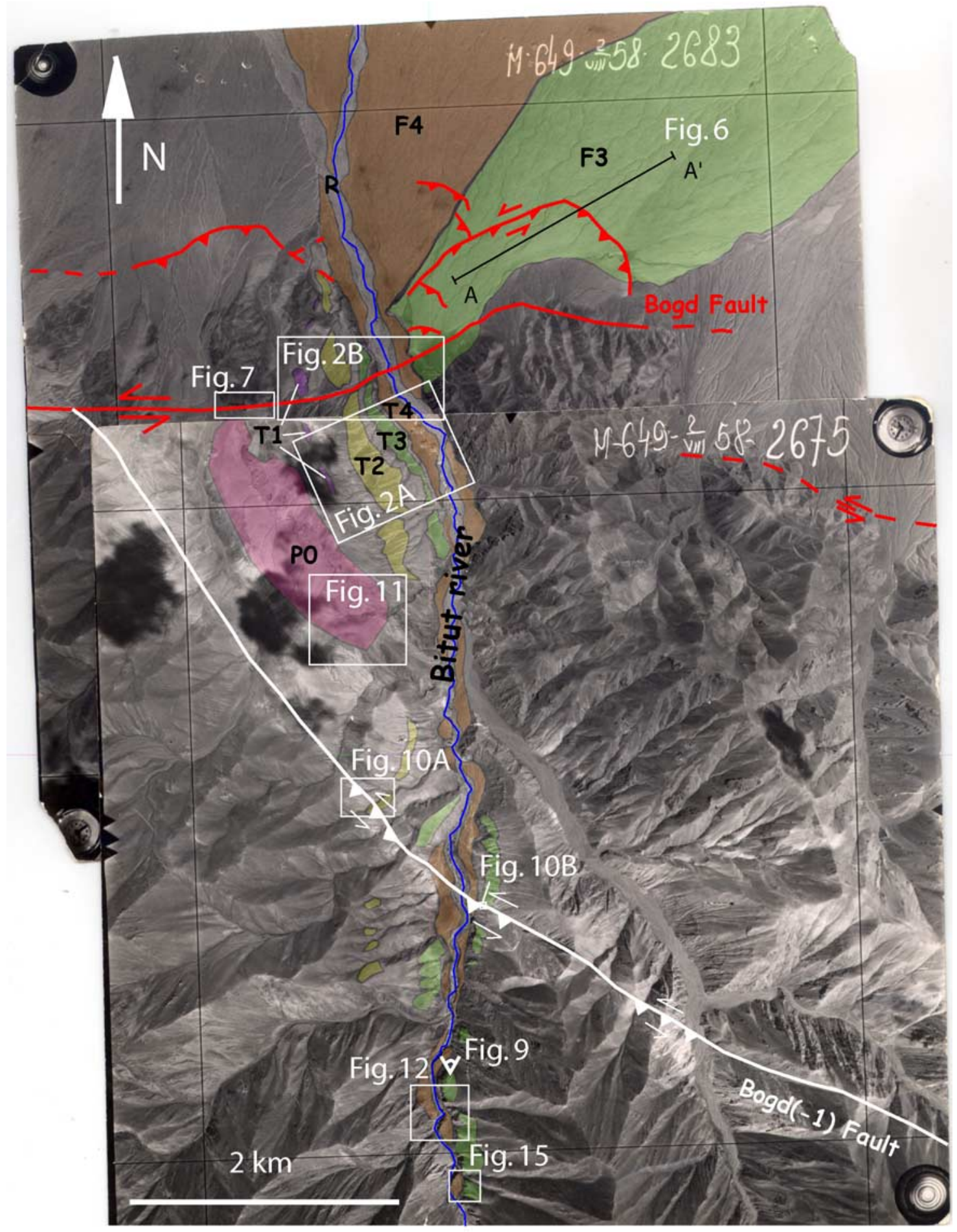

Figure 5. Cartography of the fault segments and of the alluvial surfaces along the Bitut valley on aerial $1 / 35,000$ Russian photographs of 1958. The locations of the field pictures and of the topographic profile A- $\mathrm{A}^{\prime}$ across the reverse fault scarp on the alluvial fan F3 are represented.

[16] Fluvial deposits throughout the Bitut valley are mainly debris-flows, constituted of meter-scale, often quartz-rich boulders encased in a sandy-silty matrix. The thickness of the deposits is variable from one terrace to another, ranging from a few meters up to a dozen of meters (Figure 2b). At the outlet, the oldest terrace T1 appears discontinuous and highly affected by the erosion as shown by the thinness of the deposits and by their decreasing 


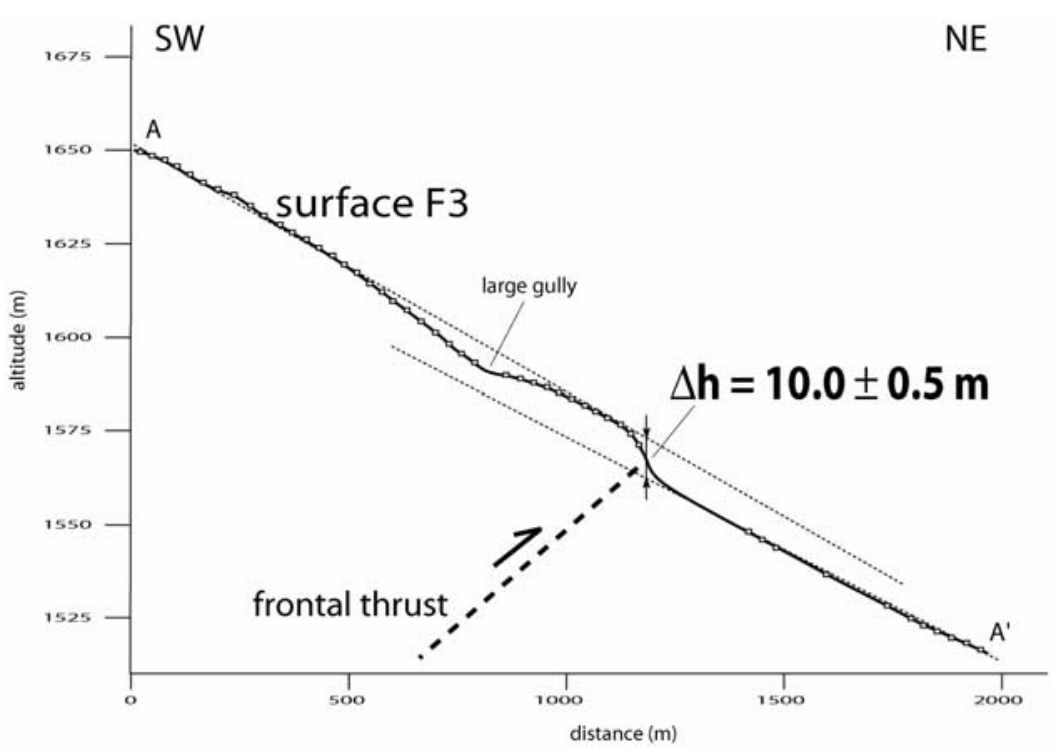

Figure 6. Topographic profile $A-A^{\prime}$ across the reverse fault scarp on the alluvial fan F3, showing a cumulated vertical offset of $10.0 \pm 0.5 \mathrm{~m}$.

thickness downstream. The few remaining weathered boulders are imbedded in the matrix, and the downstream slope of T1 surface is about $6^{\circ}$. The two intermediate terraces T2 and T3 look pretty similar to one another and are characterized by flat gently dipping surfaces (between $3^{\circ}$ and $4^{\circ}$ ), which attest of a lower denudation than T1. A few meters thick horizon of fluvial material cover the bedrock and corresponds to meter-size granite boulders encased in a sandy matrix with some of them standing above the surfaces. The youngest terrace T4 is the best preserved with a still visible bar-and-swale morphology within areas where the valley widens (intramountainous areas and outlet of the Bitut valley). Large granite boulders are forming the bars ridges, while finer material is accumulated within the swales. It is not possible to estimate the thickness of the T4 deposits under which the bedrock crops out discontinuously along short distances. The present river cuts into T4 deposits, and carries a fluvial load constituted of rounded boulders similar to those found within the terraces. The thickness of this alluvial load is unknown, as well as the depth of the bedrock under the present riverbed. The bedrock strath level of terrace T4 becomes visible $\sim 5 \mathrm{~km}$ upstream (Figure 9). Like the older abandoned strath levels, T4 strath level appears as a roughly planar surface.

\subsection{Upstream the Bitut Valley}

[17] Except T1, the other three terraces can be followed upstream for several kilometers. Four kilometers upstream the outlet, T2 appears affected by a reverse-oblique fault sub-parallel to the main Bogd fault, that we called the "Bogd(-1)" fault. This fault trends $\mathrm{N} 120^{\circ} \mathrm{E}$ and dips $70^{\circ} \mathrm{S}$ (Figures 5 and 10a). T2 deposits are thicker in the footwall than in the hangingwall and the T2 base level is vertically offset by $\sim 10 \mathrm{~m}$. The fault does not affect the strath terrace T3 showing that its activity ceased between the abandonment of $\mathrm{T} 2$ and the formation of $\mathrm{T} 3$.
[18] Within the bedrock (micaschists), a gouge zone 0.5 to $2 \mathrm{~m}$ thick (Figure 10b) shows left-lateral wrenching criteria, that we observed over several kilometers along the $\operatorname{Bogd}(-1)$ fault. Slip indicators within the fault zone have a pitch of $30^{\circ}$ to the West, showing that a reverse component is associated to the strike-slip one. Further west, this fault bends progressively to the North, where it separates the relief to the South from a wide and sub-planar surface to the North labeled P0 (Figures 5 and 11). This surface is incised, but its original geometry and contour can be easily identified in the field, as well as on air photographs: it corresponds to a perched remnant surface of $\sim 3 \mathrm{~km}$ long by $\sim 1 \mathrm{~km}$ wide. On its top, where it is the best preserved, the surface contains few weathered boulders (Figure 11). We interpreted this surface as an ancient piedmont at the footwall of the Bogd(-1) fault during an earlier stage of the mountain building process (Figure 4).

[19] At the middle reaches of the drainage basin, about $7 \mathrm{~km}$ from the northern mountain-piedmont junction, the valley narrows and only the two younger terraces, T4 and T3, are preserved (Figure 12). T4 appears as a flat, gently downstream dipping surface with standing boulders, while T3 is clearly affected by stronger erosion as shown by its tread dipping toward the valley axis. A $25 \mathrm{~m}$ deep canyon cuts into terrace T4 and the underlying bedrock. At this site, the canyon is almost free of alluvial material. The present alluvial load fills up progressively the canyon downstream (Figure 9).

\subsection{Heights of the Strath Levels Along the Bitut Valley}

[20] At the outlet of the valley, the heights of the strath levels of the three older terraces (T1 to T3) above the alluvial riverbed, which is filled by an unknown thickness of sediments, are $80 \pm 5 \mathrm{~m}, 35 \pm 3 \mathrm{~m}$, and $9 \pm 1 \mathrm{~m}$, respectively (Figure 13). Inside the massif, where the river is almost sediment-free and flows in a narrow canyon 
W

$\mathrm{E}$

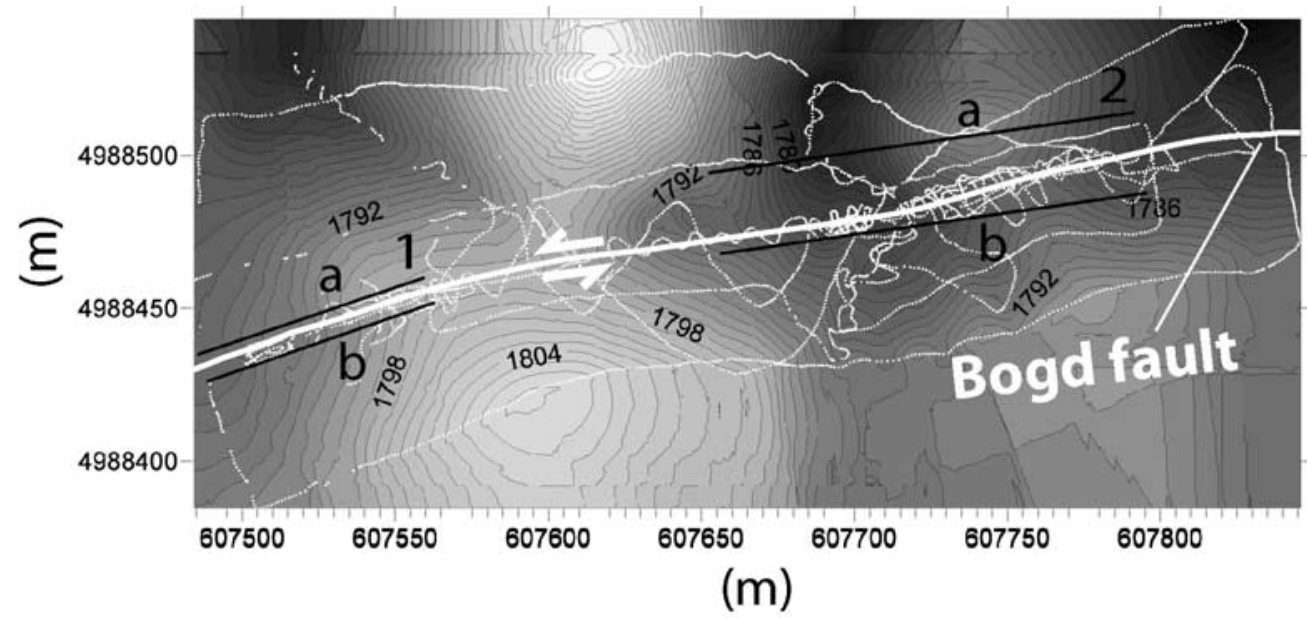

1

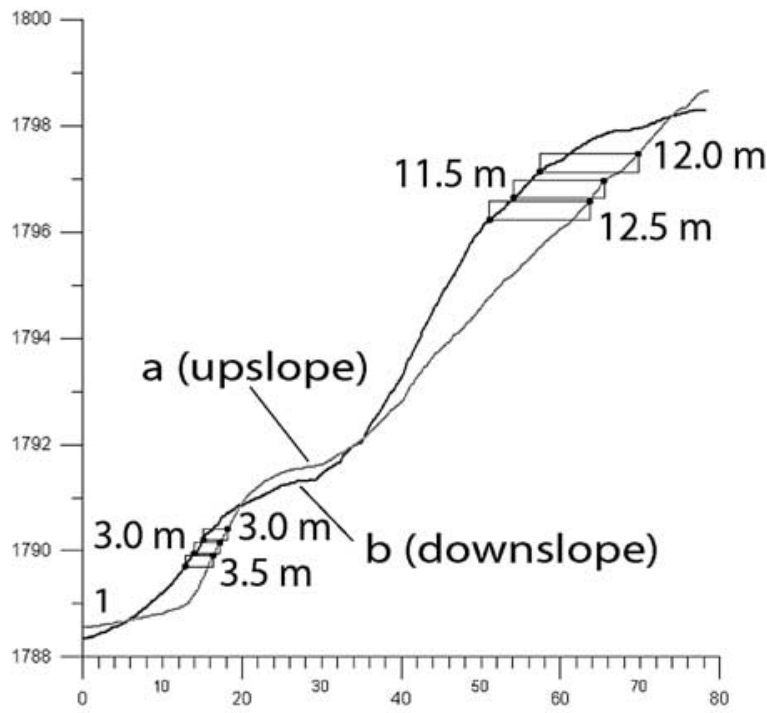

2

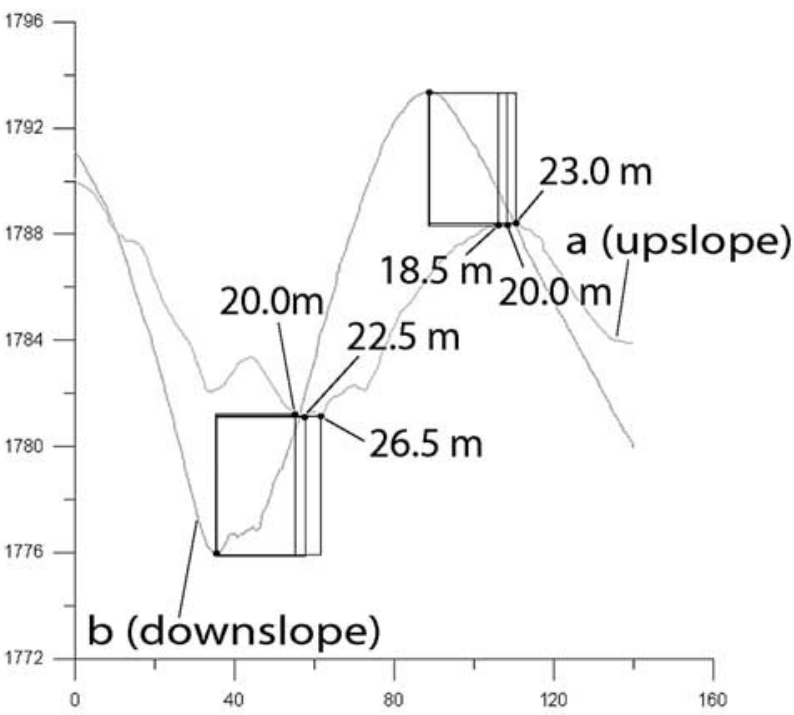

Figure 7. (a) Digital map of the site surveyed by kinematic GPS along the Bogd fault, $1 \mathrm{~km}$ to the west of the Bitut valley. Topographic data and location of profiles 1 and 2 are represented. (b) Topographic profiles 1a, 1b, 2a and 2b, upslope and downslope the fault, allowing to estimate lateral offsets of different morphotectonic markers. Lateral offsets are calculated subtracting the apparent vertical offsets (height of the rectangles) determined by the general slope of the topography toward the North, and by measuring the horizontal distance between markers offset by the fault (stream channels, hill's flanks, ridges).

carved in the bedrock, T4 and T3 are situated $25 \pm 2 \mathrm{~m}$ and $90 \pm 5 \mathrm{~m}$ above the riverbed, respectively (Figure 12). Between these two sites, strath levels diverge progressively along a vertical axis (Figure 14).

\section{4. ${ }^{10}$ Be Analysis}

[21] We used in situ produced ${ }^{10} \mathrm{Be}$ to determine the concentrations in quartz from granite boulders exposed within the terraces. This method allows dating quartz-rich material over few hundred thousand years [e.g., Lal, 1991; Brown et al., 1991; Brook et al., 1993; Bierman, 1994; Gosse and Phillips, 2001; Jackson et al., 2002]. In the age calculation, the ${ }^{10} \mathrm{Be}$ inheritance and the alluvial surface erosion rate are key parameters, which relative importance depends on the age of the terrace. The importance of the inheritance is larger when surfaces are younger than a few tens of thousand years, while the importance of the erosion becomes significant when dealing with surfaces older than about fifty thousand years [e.g., Anderson et al., 1996; 


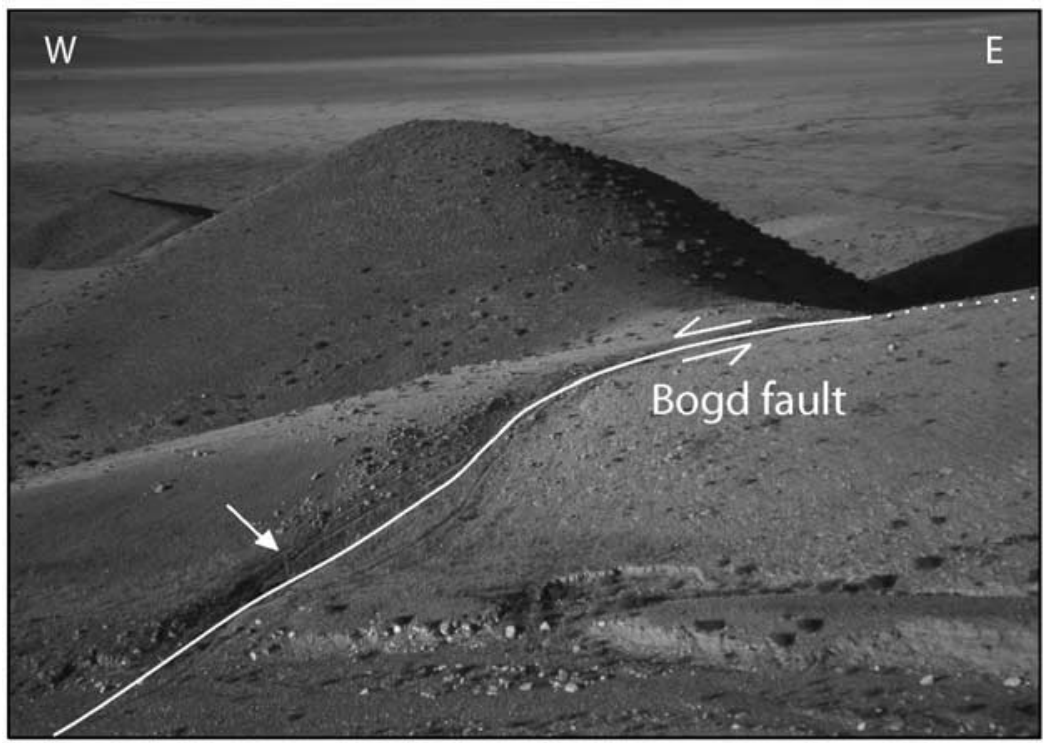

Figure 8. Photograph of the left-lateral strike-slip Bogd fault at the site described in Figure 7. The arrow indicates a person giving the scale (photo by J-F. Ritz).

Siame et al., 2000; Ritz et al., 2006]. We therefore adapted our sampling strategy in consequence.

[22] Sampling has been carried out at the outlet of the Bitut valley for all the surfaces, and at different points along the valley for $\mathrm{T} 3$ and $\mathrm{T} 4$, which is the only continuous and well-preserved marker over several kilometers. For the youngest strath terrace (T4) we sampled tops and, when possible, bottoms of surficial boulders. For the oldest terrace (T1), we only sampled outcropping boulders, while for the intermediate terraces T2 and T3, we collected samples both at surface and in soil pits up to $2 \mathrm{~m}$ deep, in order to analyze the ${ }^{10} \mathrm{Be}$ distribution at depth. For these three older strath terraces, surficial boulders are largely encased in the matrix and present dark varnish diminishing from their top to the ground level. All boulders sampled are granitoids. They are $\sim 1 \mathrm{~m}$ diameter in average, standing out of the ground surface up to a few tens of centimeters, and were sampled in their upper part to minimize the shielding factor. Cobbles collected within the soil pits are $\sim 10 \mathrm{~cm}$ diameters in average.

[23] At the middle reaches of the drainage basin, where a $25 \mathrm{~m}$ incision is observed in the bedrock, we sampled a vertical profile of $11 \mathrm{~m}$ in a quartz vein along one of the walls of the canyon (Figure 15). The exposure age of this wall corresponds to a minimum age for the last major incision that affected the massif. It also allows a comparison with the dating of T4 deposits capping the top of the strath terrace, and whose time of abandonment should be the same of the canyon formation.

[24] Samples were prepared following the chemical procedures described by Brown et al. [1991]. ${ }^{10} \mathrm{Be}$ analyses were performed at the Tandétron Accelerator Mass Spectrometry Facility, Gif-sur-Yvette (INSU-CNRS, France) [Raisbeck et al., 1987]. The ${ }^{10} \mathrm{Be}$ analyses were calibrated against NIST Standard Reference Material 4325 using its certified ${ }^{10} \mathrm{Be} /{ }^{9} \mathrm{Be}$ ratio of $(2.68 \pm 1.4) \cdot 10^{-12}$. Production rates have been calculated following Stone [2000] using the modified scaling functions of $\mathrm{Lal}$ [1991] and a modern ${ }^{10} \mathrm{Be}$ production rate in quartz of $5.1 \pm 0.3$ atoms. $\mathrm{g}^{-1} \mathrm{yr}^{-1}$ at sea level and high latitude. Because incoming cosmic rays are shielded by the surrounding topography, geomorphic scaling factors have been calculated following Dunne et al. [1999]. Exposure ages were calculated by using the estimates of the contribution of the nuclear particles proposed by Braucher et al. [2003]. For the soil profiles, we modeled theoretical curves from the data using the Chi-square inversion procedure described by Ritz et al. [2006] (cf. Appendix for more details).

\subsection{Results of the ${ }^{10} \mathrm{Be}$ Analysis}

[25] The results of the ${ }^{10} \mathrm{Be}$ analysis are presented in Table 1, and in Figures 16 and 17. At the outlet of Bitut valley, the results show that, for each terrace, surficial concentrations are similar among boulders. Only a few outlying data have significantly different values $(>2 \sigma$ uncertainty intervals), and were not taken into account for surface dating (see discussion in Appendix).

[26] The terrace T2, with the exception of one outlier of $\mathrm{T} 4$, has the highest ${ }^{10} \mathrm{Be}$ concentrations among the four terraces (between $2.08 \pm 0.12$ and $1.69 \pm 0.15 \mathrm{Mat} / \mathrm{g}$, with an outlier at $1.23 \pm 0.74 \mathrm{Mat} / \mathrm{g})$. The terrace $\mathrm{T} 1$ and the terrace $\mathrm{T} 3$ have similar ${ }^{10} \mathrm{Be}$ concentrations to one another. The ${ }^{10} \mathrm{Be}$ concentrations of terrace $\mathrm{T} 1$ are comprised between $1.62 \pm 0.13 \mathrm{Mat} / \mathrm{g}$ and $1.13 \pm 0.08 \mathrm{Mat} / \mathrm{g}$. For the terrace T3 they are comprised between $1.49 \pm 0.19 \mathrm{Mat} / \mathrm{g}$ and $1.21 \pm 0.22 \mathrm{Mat} / \mathrm{g}$, with two outliers at $7.95 \pm 0.08$ and $7.46 \pm 0.27 \mathrm{Mat} / \mathrm{g}$. The terrace T4 has the lowest concentrations (clustered between $0.11 \pm 0.06 \mathrm{Mat} / \mathrm{g}$ and $0.40 \pm$ 


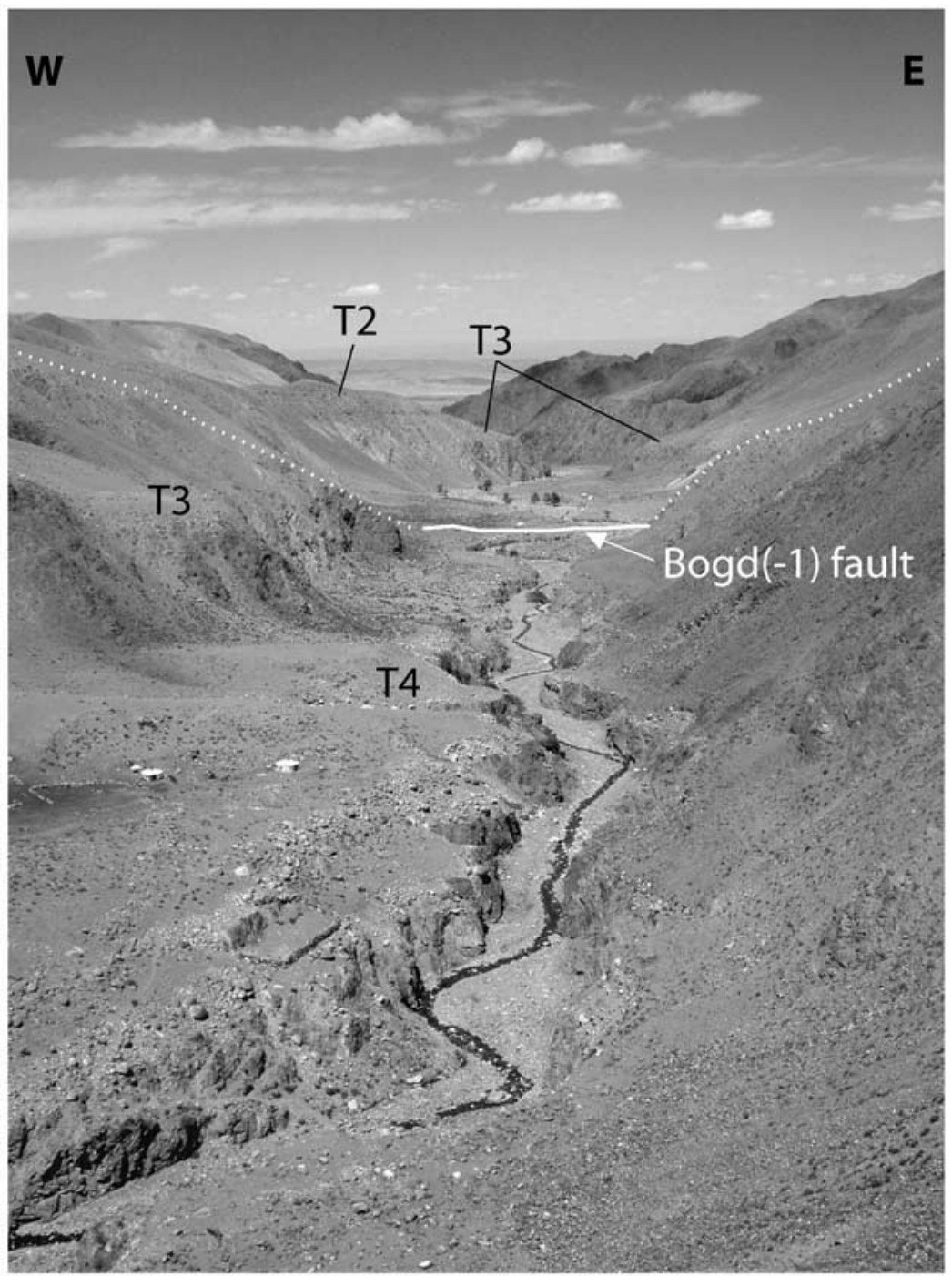

Figure 9. Photograph of the Bitut valley showing the progressive downstream filling of the canyon by present river sediments. The canyon completely disappears at the level of the Bogd(-1) fault (photo by R. Braucher).

$0.05 \mathrm{Mat} / \mathrm{g}$ ), and presents two outliers with higher concentrations. One of them (MO-03-29) has the highest concentration of the four terraces $(4.47 \pm 0.32 \mathrm{Mat} / \mathrm{g})$, which is also the highest concentration ever found within the Gurvan Bogd mountain range. Except this sample, concentrations of T4 are quite homogeneous all along the sampled section of the Bitut valley (about $7 \mathrm{~km}$ ). On the contrary, samples of T3 along the same section, where the terrace is less preserved and the cross-valley terrace tread slope is higher, show lower concentrations than $\mathrm{T} 3$ at the outlet.

[27] The distribution of the ${ }^{10} \mathrm{Be}$ concentration as a function of depth along the depth profiles within $\mathrm{T} 2$ and T3 shows in both cases an exponential decrease, as theoretically predicted by physical laws [e.g., Brown et al., 1991] (Figure 17). This means that the fraction of inherited ${ }^{10} \mathrm{Be}$ of most of the samples, even though we cannot estimate it precisely, is small with respect to the post- depositional one. However, for both surfaces, the scattering of the ${ }^{10} \mathrm{Be}$ distribution with respect to the theoretical profiles proves that samples contain inherited ${ }^{10} \mathrm{Be}$ in variable quantities. This scatter determines a low goodness of fit for Chi-square models (Q value $<0.001$, Press et al., 1996), preventing the estimation of erosion rates. Consequently, the dating of these terraces has to be made with an assumption of negligible erosion, which yields minimum ages. The upper samples of each profile (MO-03-T2-TOP and MO-03-T3-0) are cobbles found at the level of the ground surface. In both cases they have a slightly lower concentration than the mean value given by the boulders (Table 1).

[28] As concerns the dating of terrace T4, two of the three boulders that have been sampled at their top and bottom show similar ${ }^{10} \mathrm{Be}$ concentrations (0.1-0.2 Mat/g) for the upper and lower parts (Table 1 and Figure 16). These results 

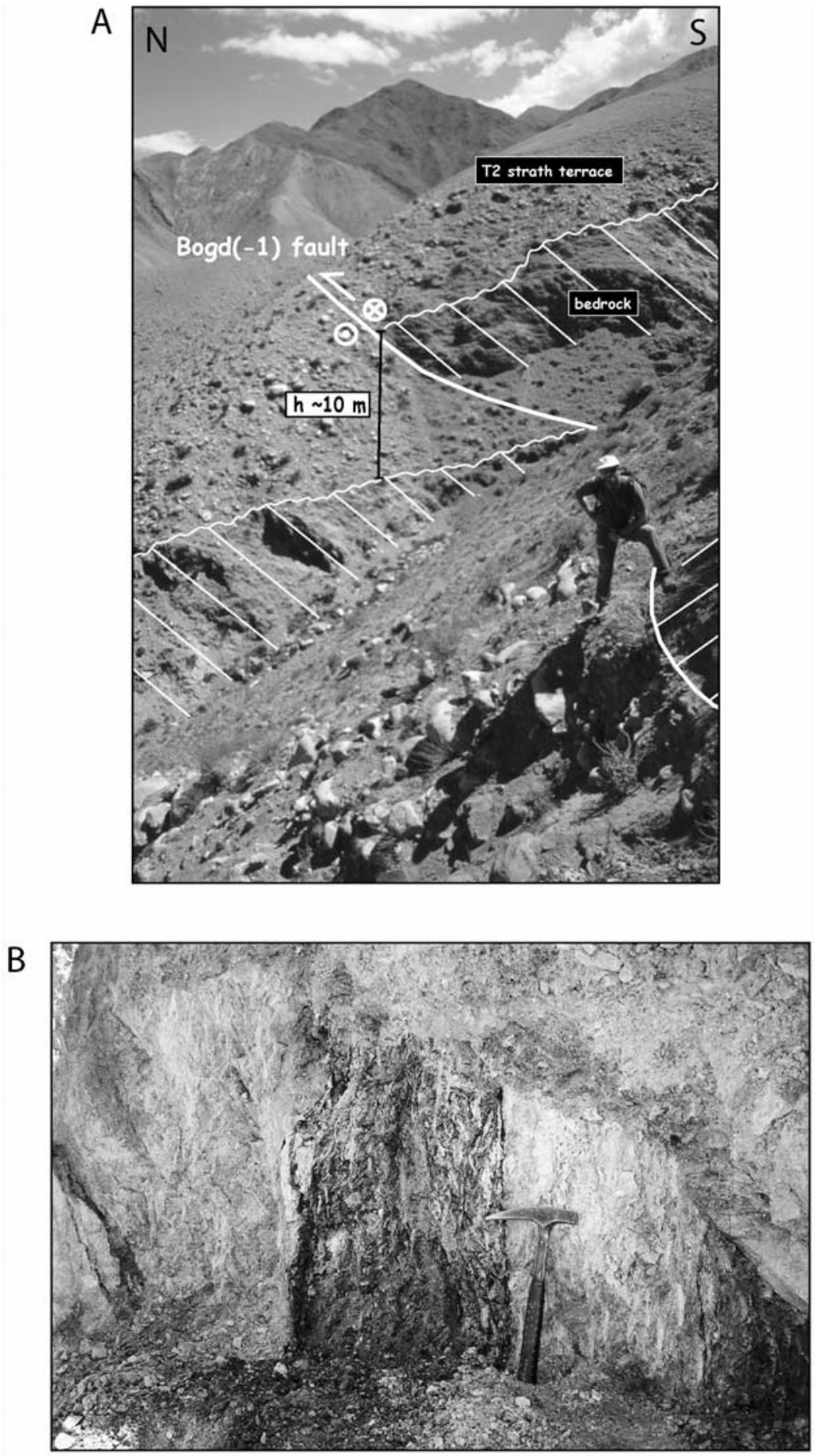

Figure 10. (a) Vertical offset of $\sim 10 \mathrm{~m}$ of the base level of the alluvial terrace $\mathrm{T} 2$ along the Bogd(-1) fault (photo by J-F. Ritz). (b) Sub-vertical gouge along the same fault zone, within the micaschists formation situated just north of a tectonic contact with gneisses (photo by A. Chauvet).

are incompatible with a simple exposure in the present position, and imply that most of the ${ }^{10} \mathrm{Be}$ at the bottom of the boulder accumulated before the abandonment of the terrace. They also suggest that a fraction of the top concen- tration is not post-depositional and the exposure age determined using the concentrations of the boulders of T4 should be therefore considered as a maximum one. The bottom of the third boulder has a concentration in the same range, 

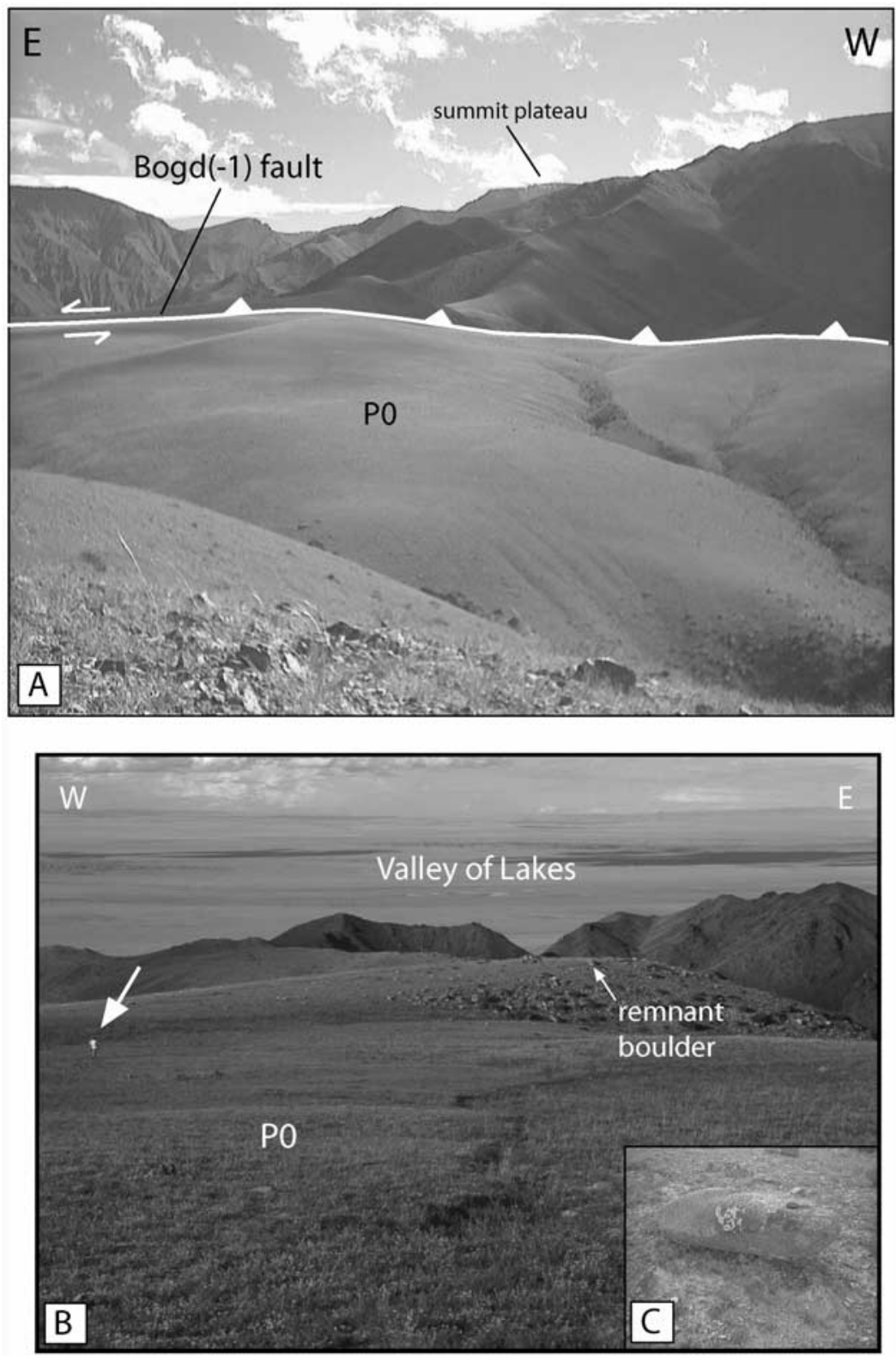

Figure 11. (a) View upslope of the piedmont surface P0 and of the Bogd(-1) fault (photo by R. Vassallo). (b) View downslope of the same surface, with the present piedmont in the background. The big arrow indicates a person giving the scale (photo by J-F. Ritz). (c) Typical metre-scale boulder encased in this surface (photo by R. Vassallo).

while the top has a much higher concentration with respect to the mean of the surface, implying a complex preexposure history.

[29] The vertical profile in the bedrock at the middle reaches of the drainage basin show very low ${ }^{10} \mathrm{Be}$ concentrations, going from $21200 \pm 5300 \mathrm{at} / \mathrm{g}$ at the top, to $6900 \pm$ $3400 \mathrm{at} / \mathrm{g}$ at the bottom.

\subsection{Estimating Exposure Ages}

[30] As concerns the estimation of the ages of the abandonment of the terraces $\mathrm{T} 2$ and $\mathrm{T} 3$, the distribution of the ${ }^{10} \mathrm{Be}$ concentration at depth shows that the inherited ${ }^{10} \mathrm{Be}$ is negligible with respect to the total concentration (Figure 17). To calculate the ages of these two surfaces we therefore took the samples with the highest concentrations $(2.08 \pm 0.12 \mathrm{Mat} / \mathrm{g}$ and $1.49 \pm 0.19 \mathrm{Mat} / \mathrm{g}$, respectively $)$ among the surficial boulders standing above the surfaces, and we assumed no erosion. This yields minimum ages for surface T2 and T3 of $106 \pm 9{ }^{10} \mathrm{Be}-\mathrm{ka}$ and $78 \pm 11{ }^{10} \mathrm{Be}-\mathrm{ka}$, respectively. These minimum ages are close to those $\left(105.5 \pm 7.0{ }^{10} \mathrm{Be}-\mathrm{ka}\right.$ and $\left.81.4 \pm 6.5{ }^{10} \mathrm{Be}-\mathrm{ka}\right)$ given by the most concentrated samples within the two alluvial fans 

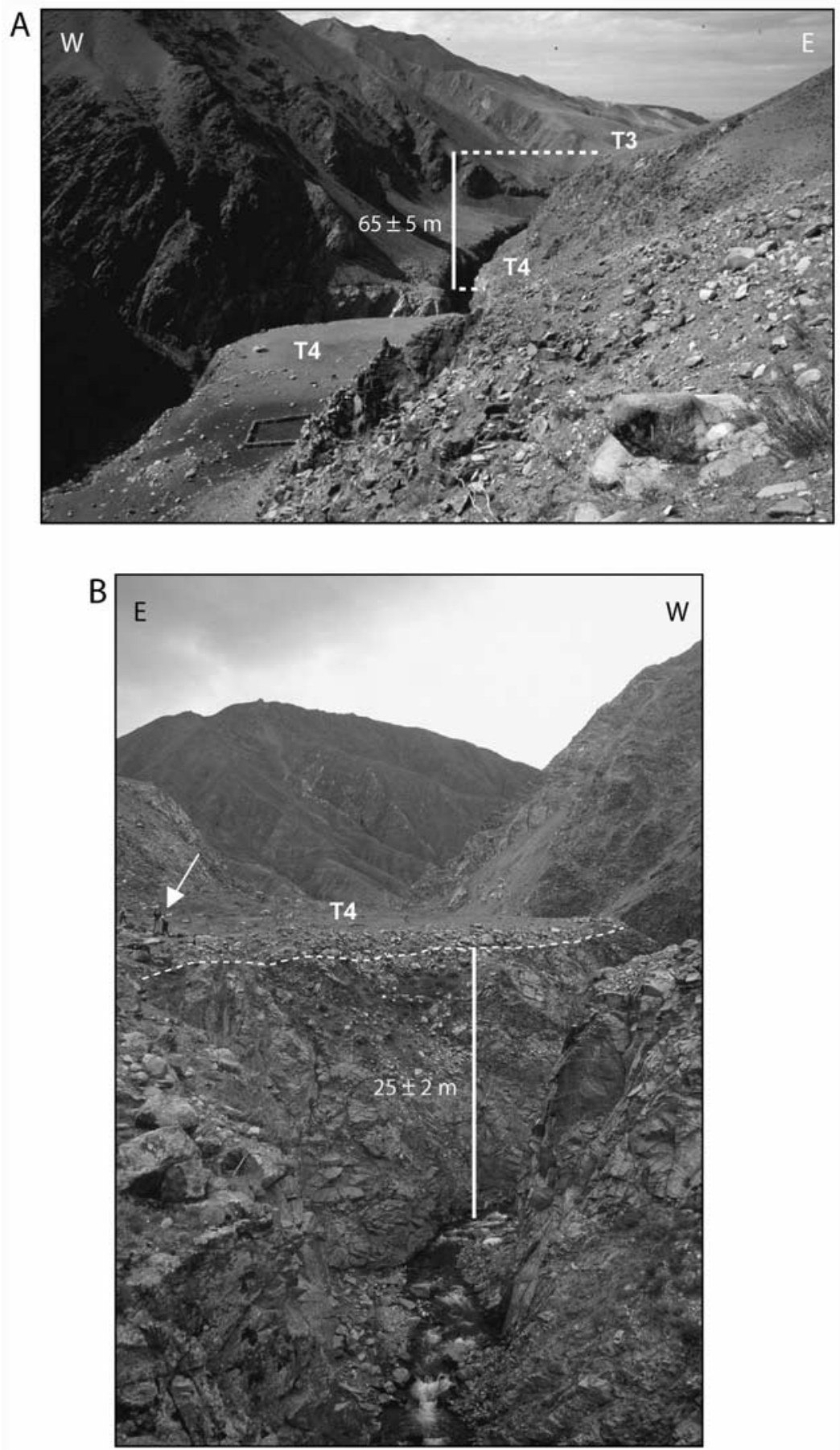

Figure 12. (a) Photograph of terraces $\mathrm{T} 3$ and $\mathrm{T} 4$ at the middle reaches of the Bitut basin. (b) Photograph of the canyon carved into the bedrock under terrace T4. The arrow shows people for scale (photos by R. Vassallo).

$\mathrm{S} 2$ and $\mathrm{S} 1$ (displacement of surface $\mathrm{S} 2$ is twice that of S1) studied by Ritz et al. [1995] $50 \mathrm{~km}$ further west in Noyan Uul. These two fans were interpreted as aggradational events associated to two climatic pulses having occurred at transitions between glacial and interglacial stages. Analyzing the ${ }^{10} \mathrm{Be}$ distribution at depth along soil profiles,
Vassallo et al. [2005] concluded that these two fans formed at the transitions between Marine Isotope Stages MIS 8 and MIS 7 (245-230 ka), and between MIS 6 and MIS 5 (125$110 \mathrm{ka})$, respectively. It is therefore reasonable to consider that terraces $\mathrm{T} 2$ and $\mathrm{T} 3$ correspond to the same climatic pulses. As in Noyan Uul, we interpret the small difference 

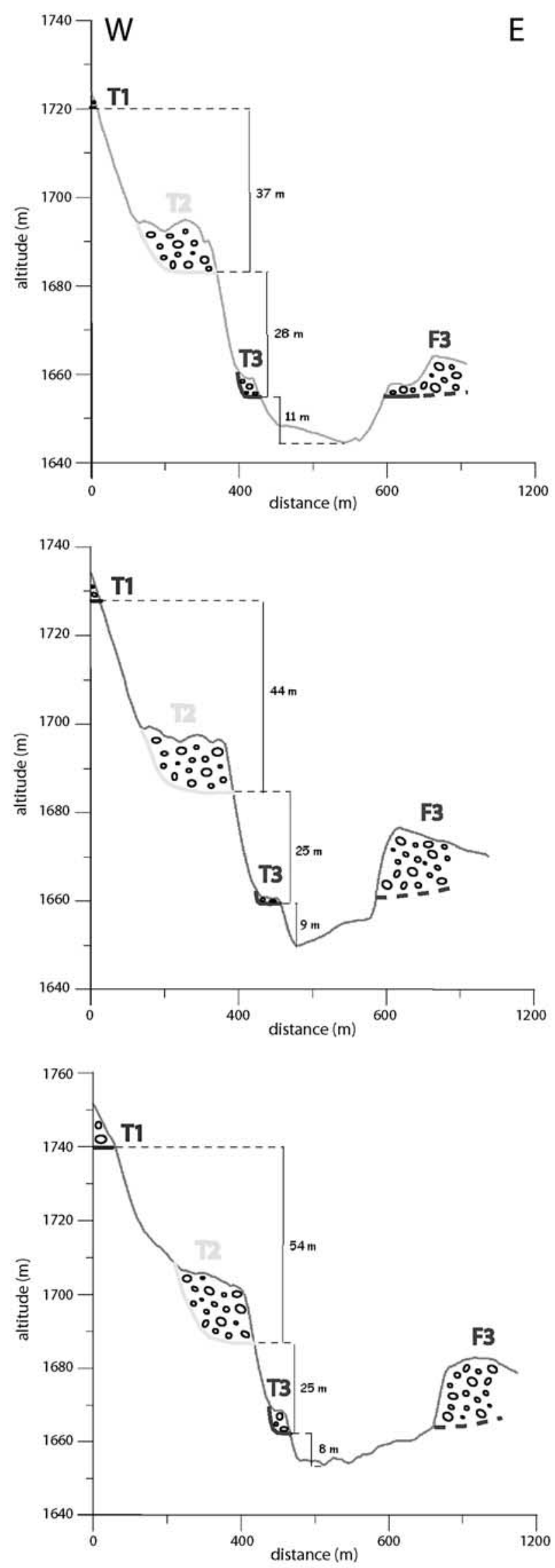

between the ${ }^{10} \mathrm{Be}$ concentrations of terraces $\mathrm{T} 2$ and $\mathrm{T} 3$ as concentrations approaching steady state values.

[31] The fact that $\mathrm{T} 1$, the most elevated terrace and therefore the oldest morphologically speaking, shows a lower ${ }^{10} \mathrm{Be}$ concentration than $\mathrm{T} 2$ and $\mathrm{T} 3$, means that the concentration of this surface is at steady state with a higher erosion rate [see Brown et al., 1991]. Thus the mean surficial ${ }^{10} \mathrm{Be}$ concentration of this terrace let us calculate a maximum erosion rate of $9 \pm 2 \mathrm{~m} / \mathrm{Ma}$. The evolution of the concentration through time for such an erosion rate shows that $95 \%$ of the present ${ }^{10} \mathrm{Be}$ concentration is reached toward $250 \mathrm{ka}$, which therefore represents a minimum age for this terrace. The abandonment of this terrace could be related to the previous transition from a glacial to an interglacial period, between the end of the MIS 10 and the beginning of the MIS 9 (340-330 ka).

[32] The age of T4 both at the outlet and at the middle reaches of the Bitut basin is disturbed by the inherited ${ }^{10} \mathrm{Be}$, whose value is often comparable to or higher than the postdepositional concentration. Because it is difficult to know the amount of inheritance in each boulder and because the post-depositional erosion is largely negligible for such young surfaces, we consider that the age calculated for this terrace is a maximum one. Therefore the youngest apparent age, given by the boulder with the smallest concentration at the top, should be the closest to the true age. Sample MO03-51, error bars included, is the least concentrated one $(0.12 \pm 0.02 \mathrm{Mat} / \mathrm{g})$ and yields a maximum exposure age of $4.5 \pm 0.8{ }^{10} \mathrm{Be}-\mathrm{ka}$.

[33] Upstream, inside the massif, the low concentrations along the bedrock profile ( $\sim 0.01 \mathrm{Mat} / \mathrm{g})$, situated just below $\mathrm{T} 4$, shows that the sampled wall is at the surface since only $0.5 \pm 0.1 \mathrm{ka}$. Our interpretation is that this young age is related to the recent widening of the canyon due to lateral collapse associated to river sapping.

\section{Determining Incision and Slip Rates}

\subsection{Incision Rate at the Outlet}

[34] At the outlet of the Bitut basin, the recent filling of the riverbed disturbs the determination of the incision rates related to the abandonment of the strath terraces. Since the general base level of terrace T4 is situated under the level of the present riverbed, it is not possible to determine the Holocene incision rate at this site. For the calculation of the incision rates between $\mathrm{T} 4$ and the other strath terraces, we assume that the present riverbed approximates the position of the base level of T4. Differences in heights are $9 \pm 2 \mathrm{~m}$ between $\mathrm{T} 3$ and $\mathrm{T} 4,35 \pm 3 \mathrm{~m}$ between $\mathrm{T} 2$ and $\mathrm{T} 4$, and $80 \pm$ $5 \mathrm{~m}$ between $\mathrm{T} 1$ and $\mathrm{T} 4$. Interpreting our exposure ages (see above) we considered the following ages for the terraces abandonment: $5 \mathrm{ka}$ for T4, 110 ka for T3, $230 \mathrm{ka}$ for T2, and $330 \mathrm{ka}$ for $\mathrm{T} 1$.

Figure 13. Transversal sections across the river at the outlet of Bitut valley and vertical differences in height between the strath terraces T1-T2, T2-T3, and T3-riverbed. 


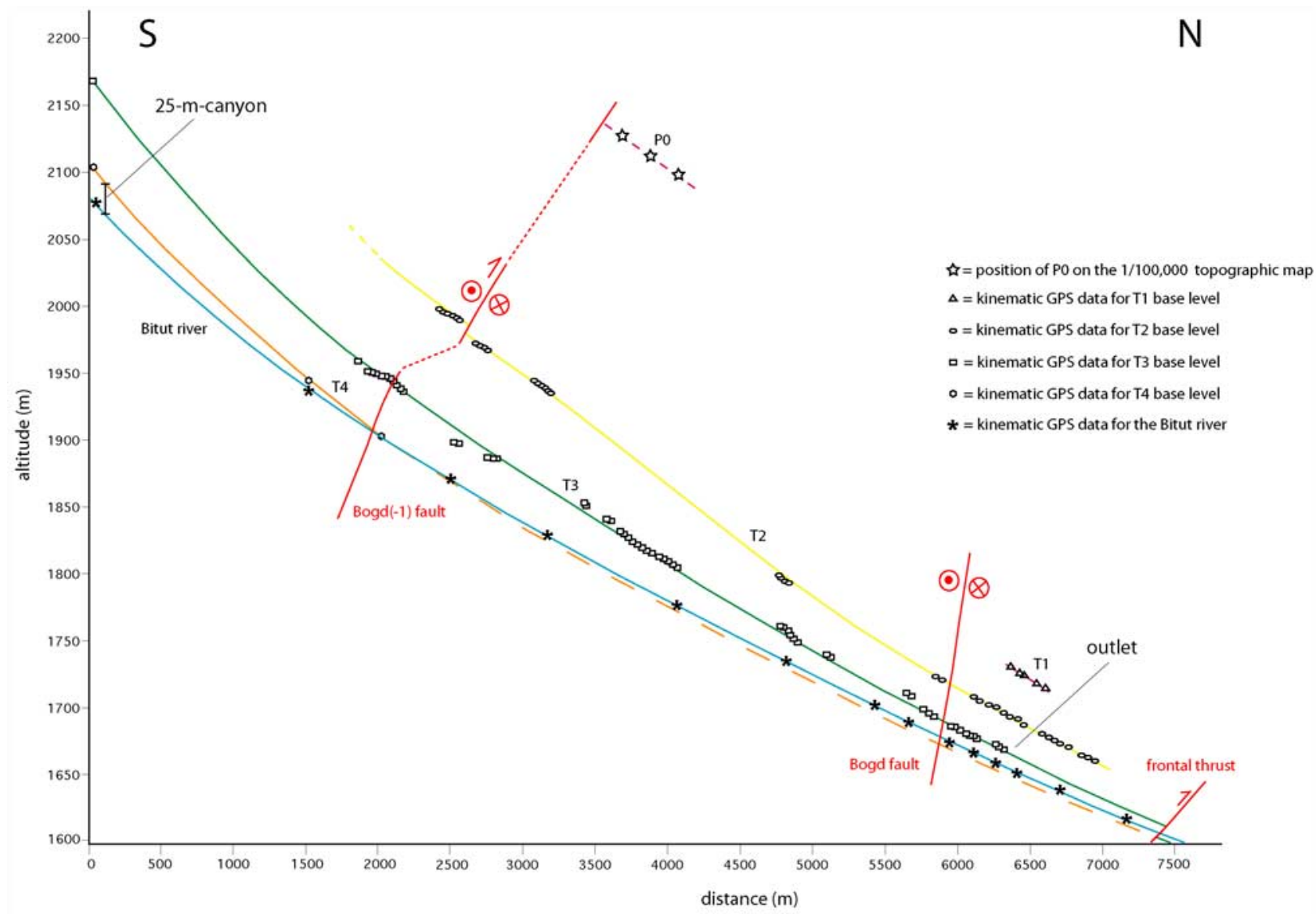

Figure 14. Longitudinal profiles of the base levels of the strath terraces along the Bitut river, obtained from kinematic GPS data and 1/100,000 Russian topographic map.

[35] This yields the following values for the incision rates: $0.10-0.15 \mathrm{~mm} / \mathrm{yr}$ for the period comprised between the abandonment of T3 and that of T4, $0.15-0.20 \mathrm{~mm} / \mathrm{yr}$ for the period T2-T4, and $0.20-0.30 \mathrm{~mm} / \mathrm{yr}$ for the period T1-T4. Therefore the incision rate is comprised in the range $0.10-0.30 \mathrm{~mm} / \mathrm{yr}$ during the last $\sim 330 \mathrm{ka}$, and characterized by a slight decrease through time. This trend is more obvious if, considering the constant periodical formation of the strath terraces during the interglacial periods every $\sim 100 \mathrm{ka}$, we look at the differential height between the successive strath levels T1-T2, T2-T3 and T3-T4 (45 m, $26 \mathrm{~m}$, and $9 \mathrm{~m}$, respectively; the last one being a minimum). This decrease can be due to the growth of the drainage network, inducing a progressive decrease of the river slope, or to the decrease of the uplift rate of the massif, or both.

\subsection{Incision Rate Inside the Massif}

[36] At the middle reaches of the drainage basin, about $7 \mathrm{~km}$ upstream the outlet of Bitut valley, the incision rates can be calculated from the strath levels of T4 and T3 terraces - the only two terraces preserved in this part of the Bitut valley - with respect to the present-day bedrock river. Incision rates are calculated taking into account the same exposure ages used at the outlet $(5 \mathrm{ka}$ and $110 \mathrm{ka}$ for
$\mathrm{T} 4$ and $\mathrm{T} 3$, respectively) and the differences in height between T4 strath level and the present riverbed $(25 \pm 2 \mathrm{~m})$, and between $\mathrm{T} 3$ and $\mathrm{T} 4$ strath levels $(65 \pm 5 \mathrm{~m})$. This yields an incision rate of $5.0 \pm 1.0 \mathrm{~mm} / \mathrm{yr}$ over the last $5 \mathrm{ka}$, and an incision rate of $0.6 \pm 0.1 \mathrm{~mm} / \mathrm{yr}$ between $110 \mathrm{ka}$ and $5 \mathrm{ka}$.

[37] These values are higher than those estimated at the outlet with the same terraces. We believe that this variation is related to the growth of the hydrographic network, which effects are magnified in the higher course of the river, rather than to the effect of variable slip rate (taking into account that the erosional summit surface is horizontal and flat precludes the interpretation of tilting/folding of the massif). The growth of the hydrographic network is also shown by the decrease in the incision heights between T3-T4 and T4riverbed (65 $\mathrm{m}$ and $25 \mathrm{~m}$, respectively, at the same site). However, note that the incision rate calculated for the last $\sim 5 \mathrm{ka}$ is very high $(5.0 \pm 1.0 \mathrm{~mm} / \mathrm{yr})$ and much larger than the one estimated for the upper Pleistocene $(0.6 \pm 0.1 \mathrm{~mm} / \mathrm{yr})$.

\subsection{Vertical Slip Rate}

[38] We calculated the vertical slip rate on the reverse segment of the Bogd fault, at the outlet of the Bitut valley, considering that the abandonment of the upstream part of alluvial fan F3 should have been almost synchronous of the 


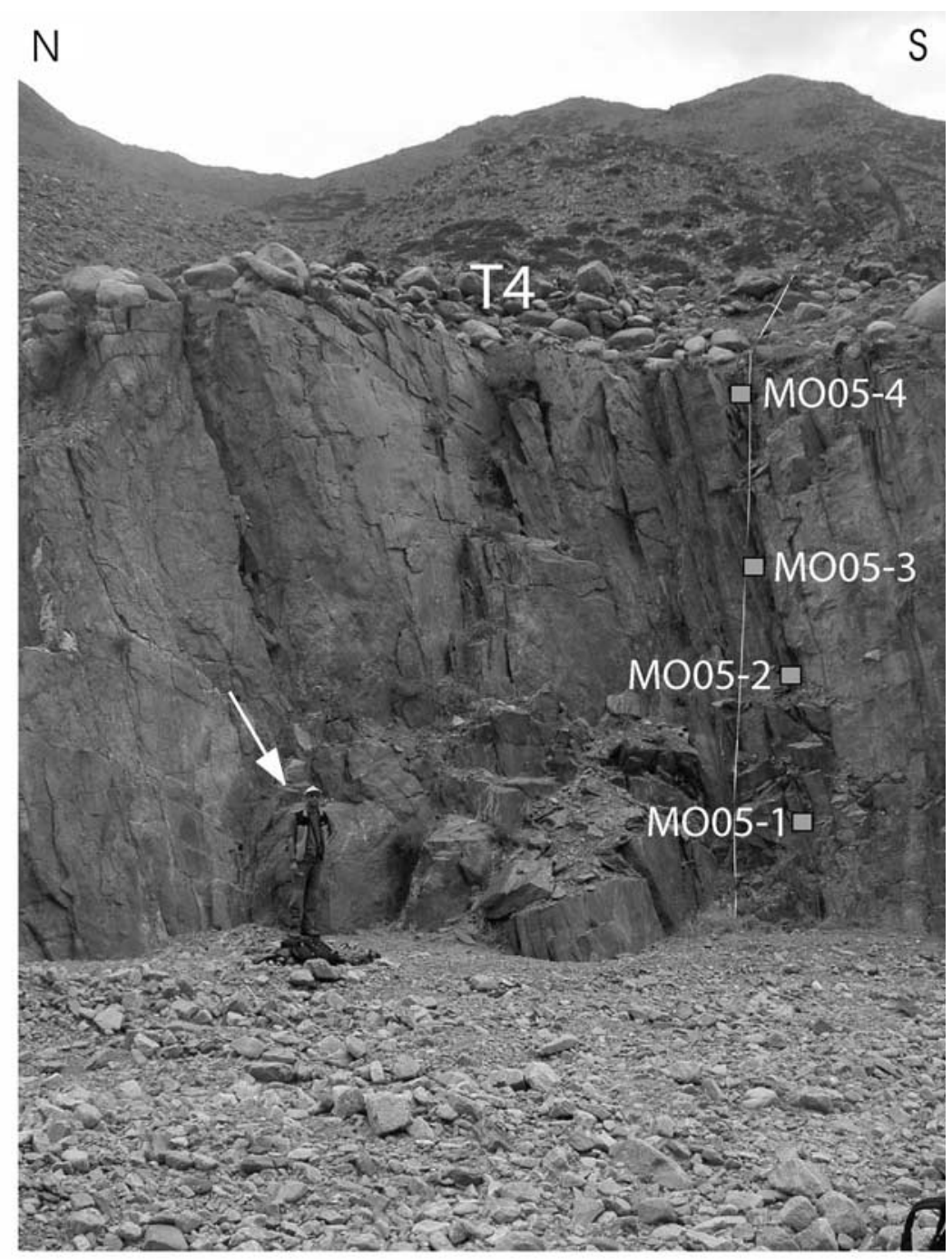

Figure 15. Photograph of the sampled wall in the bedrock along a quartz vein at the middle reaches of the Bitut basin. The arrow indicates a person giving scale (photo by R. Braucher). At this site the canyon is partially refilled because of the proximity to a small landslide, occurred in 1957 after the M8.3 earthquake, stopping the sedimentary flux downstream.

abandonment of the strath terrace T3 at the outlet $(\sim 110 \mathrm{ka})$. Dividing the vertical offset of $\sim 10 \mathrm{~m}$ by this age yields a vertical slip rate of $0.09-0.10 \mathrm{~mm} / \mathrm{yr}$. This result is consistent with the slip rates obtained on other reverse segments within the Gurvan Bogd system [Hanks et al., 1997; Ritz et al., 2003; Vassallo et al., 2005; Ritz et al., 2006].

\section{Discussion}

\subsection{Interpreting Incision Rates in Terms of Uplift Rates and Fluvial Dynamics}

[39] The uplift of the massif is mostly controlled by the reverse faulting process occurring along its boundaries. On the northern flank, the Bogd fault accommodates the totality of the vertical deformation since 200-100 ka, when the Bogd(-1) fault ceased its activity (see next sub-section).
Therefore the $\sim 0.1 \mathrm{~mm} / \mathrm{yr}$ vertical slip rate estimated for the reverse Bogd fault corresponds to the uplift rate of Ih Bogd during the last $\sim 110 \mathrm{ka}$. However, the incision rates at the outlet of the Bitut valley $(0.1-0.3 \mathrm{~mm} / \mathrm{yr})$ are up to three times the uplift rate. This difference is accounted by two other components of the fluvial incision: the local base level fall associated with alluvial fan entrenchment in the piedmont at the beginning of wet periods, and the decrease of the river slope associated with the growth of the hydrological network.

[40] The first component is demonstrated by the stepping of the successive alluvial fans at the outlet and in the upper part of the piedmont. It can correspond to a process of differential incision between the piedmont and the mountain that was theoretically proposed in a recent study using a landscape evolution model [Carretier and Lucazeau, 2005]. 
Table 1. Results of the ${ }^{10} \mathrm{Be}$ Analysis ${ }^{\mathrm{a}}$

\begin{tabular}{|c|c|c|c|c|c|c|c|}
\hline Surface & Sample & Altitude, $\mathrm{m}$ & Latitude, ${ }^{\circ} \mathrm{N}$ & Longitude, ${ }^{\circ} \mathrm{E}$ & $\mathrm{P} 0$, at $/ \mathrm{g} / \mathrm{yr}$ & $10 \mathrm{Be}, \mathrm{at} / \mathrm{g}$ & Uncertainty, at $/ \mathrm{g}$ \\
\hline T1(outlet) & MO-03-01 & 1720 & 4502.779 & 10022.278 & 20.5 & $1.35 \mathrm{E}+06$ & $1.22 \mathrm{E}+05$ \\
\hline $\mathrm{T} 1$ (outlet) & MO-03-02 & 1720 & 4502.795 & 10022.279 & 20.5 & $1.30 \mathrm{E}+06$ & $1.01 E+05$ \\
\hline $\mathrm{T} 1$ (outlet) & MO-03-03 & 1720 & 4502.795 & 10022.279 & 20.5 & $1.51 \mathrm{E}+06$ & $1.65 \mathrm{E}+05$ \\
\hline $\mathrm{T} 1$ (outlet) & MO-03-04 & 1720 & 4502.801 & 10022.280 & 20.5 & $1.62 \mathrm{E}+06$ & $1.34 \mathrm{E}+05$ \\
\hline T1(outlet) & MO-03-05 & 1720 & 4502.801 & 10022.280 & 20.5 & $1.13 \mathrm{E}+06$ & $8.41 \mathrm{E}+04$ \\
\hline $\mathrm{T} 1$ & weighted mean & & & & & $1.31 E+06$ & $5.00 \mathrm{E}+04$ \\
\hline T2(outlet) & MO-03-07 & 1690 & 4502.705 & 10022.435 & 20.1 & $2.08 \mathrm{E}+06$ & $1.17 \mathrm{E}+05$ \\
\hline T2(outlet) & MO-03-10* & 1690 & 4502.604 & 10022.586 & 20.1 & $1.23 \mathrm{E}+06$ & $7.38 \mathrm{E}+04$ \\
\hline T2(outlet) & MO-03-11 & 1690 & 4502.604 & 10022.586 & 20.1 & $1.75 \mathrm{E}+06$ & $1.08 \mathrm{E}+05$ \\
\hline $\mathrm{T} 2$ (outlet) & MO-03-12 & 1690 & 4502.604 & 10022.586 & 20.1 & $1.87 \mathrm{E}+06$ & $2.29 \mathrm{E}+05$ \\
\hline $\mathrm{T} 2$ (profile) & MO-03-T2-TOP & 1690 & 4502.604 & 10022.586 & 20.1 & $1.69 \mathrm{E}+06$ & $1.47 \mathrm{E}+05$ \\
\hline T2(profile) & MO-03-T2-40 & 1690 & 4502.604 & 10022.586 & 20.1 & $1.09 \mathrm{E}+06$ & $1.39 \mathrm{E}+05$ \\
\hline $\mathrm{T} 2$ (profile) & MO-03-T2-60 & 1690 & 4502.604 & 10022.586 & 20.1 & $8.22 \mathrm{E}+05$ & $1.66 \mathrm{E}+05$ \\
\hline T2(profile) & MO-03-T2-125 & 1690 & 4502.604 & 10022.586 & 20.1 & $3.39 E+05$ & $5.21 \mathrm{E}+04$ \\
\hline $\mathrm{T} 2$ (profile) & MO-03-T2-160 & 1690 & 4502.604 & 10022.586 & 20.1 & $4.29 \mathrm{E}+05$ & $9.93 E+04$ \\
\hline $\mathrm{T} 2$ (profile) & MO-03-T2-200 & 1690 & 4502.604 & 10022.586 & 20.1 & $1.33 \mathrm{E}+05$ & $3.08 \mathrm{E}+04$ \\
\hline T2 & weighted mean & & & & & $1.90 E+06$ & $7.49 \mathrm{E}+04$ \\
\hline T3(outlet) & MO-03-14* & 1650 & 4502.677 & 10022.602 & 19.4 & $7.95 \mathrm{E}+05$ & $8.01 E+04$ \\
\hline T3(outlet) & MO-03-16 & 1650 & 4502.677 & 10022.602 & 19.4 & $1.32 \mathrm{E}+06$ & $1.29 \mathrm{E}+05$ \\
\hline $\mathrm{T} 3$ (outlet) & MO-03-17* & 1650 & 4502.677 & 10022.602 & 19.4 & $7.46 \mathrm{E}+05$ & $2.65 E+05$ \\
\hline T3(outlet) & MO-03-18 & 1650 & 4503.189 & 10023.802 & 19.4 & $1.44 \mathrm{E}+06$ & $9.87 \mathrm{E}+04$ \\
\hline T3(outlet) & MO-03-19 & 1650 & 4503.164 & 10023.909 & 19.4 & $1.21 \mathrm{E}+06$ & $2.24 \mathrm{E}+05$ \\
\hline T3(outlet) & MO-03-21 & 1650 & 4503.253 & 10024.229 & 19.4 & $1.27 \mathrm{E}+06$ & $1.52 \mathrm{E}+05$ \\
\hline T3(outlet) & MO-03-22 & 1650 & 4503.105 & 10023.704 & 19.4 & $1.49 \mathrm{E}+06$ & $1.90 \mathrm{E}+05$ \\
\hline T3(valley) & MO-03-34* & 2230 & 4448.083 & 10022.286 & 29.4 & $5.08 \mathrm{E}+05$ & $4.50 \mathrm{E}+04$ \\
\hline T3(valley) & MO-03-54* & 2170 & 4448.083 & 10022.286 & 27.3 & $4.53 \mathrm{E}+05$ & $8.83 E+04$ \\
\hline T3(valley) & MO-05-8 & 1860 & 4501.290 & 10022.790 & 22.5 & $4.59 \mathrm{E}+05$ & $6.29 \mathrm{E}+04$ \\
\hline T3(valley) & MO-05-9 & 1860 & 4601.290 & 10122.790 & 22.5 & $8.45 \mathrm{E}+05$ & $1.26 \mathrm{E}+05$ \\
\hline T3(profile) & MO-03-T3-0 & 1650 & 4502.677 & 10022.602 & 19.4 & $1.04 \mathrm{E}+06$ & $1.33 \mathrm{E}+05$ \\
\hline T3(profile) & MO-03-T3-30 & 1650 & 4602.677 & 10122.602 & 19.4 & $7.96 \mathrm{E}+05$ & $6.49 \mathrm{E}+04$ \\
\hline T3(profile) & MO-03-T3-50 & 1650 & 4702.677 & 10222.602 & 19.4 & $4.63 E+05$ & $4.85 E+04$ \\
\hline T3(profile) & MO-03-T3-75 & 1650 & 4802.677 & 10322.602 & 19.4 & $2.65 \mathrm{E}+05$ & $3.29 \mathrm{E}+04$ \\
\hline $\mathrm{T} 3$ (profile) & MO-03-T3-100 & 1650 & 4902.677 & 10422.602 & 19.4 & $2.04 \mathrm{E}+05$ & $4.14 \mathrm{E}+04$ \\
\hline T3(profile) & MO-03-T3-120 & 1650 & 5002.677 & 10522.602 & 19.4 & $2.37 \mathrm{E}+05$ & $1.06 \mathrm{E}+05$ \\
\hline T3 & weighted mean & & & & & $1.37 E+06$ & $4.85 E+04$ \\
\hline T4(outlet) & MO-03-29* & 1640 & 4502.814 & 10022.730 & 19.4 & $4.47 \mathrm{E}+06$ & $3.18 \mathrm{E}+05$ \\
\hline T4(outlet) & MO-03-30 (T) & 1640 & 4502.536 & 10022.691 & 19.4 & $1.68 \mathrm{E}+05$ & $3.39 \mathrm{E}+04$ \\
\hline T4(outlet) & MO-03-31 (B) & 1640 & 4502.536 & 10022.691 & 19.4 & $1.93 \mathrm{E}+05$ & $3.10 \mathrm{E}+04$ \\
\hline T4(outlet) & MO-03-32 & 1640 & 4502.513 & 10022.656 & 19.4 & $3.05 \mathrm{E}+05$ & $3.16 \mathrm{E}+04$ \\
\hline T4(outlet) & MO-03-35* (T) & 1640 & 4502.811 & 10022.711 & 19.4 & $7.58 \mathrm{E}+05$ & $2.69 \mathrm{E}+05$ \\
\hline T4(outlet) & MO-03-36 (B) & 1640 & 4502.811 & 10022.711 & 19.4 & $1.52 \mathrm{E}+05$ & $2.34 \mathrm{E}+04$ \\
\hline T4(valley) & MO-03-46 & 2100 & 4459.636 & 10022.559 & 25.0 & $1.06 \mathrm{E}+05$ & $6.12 \mathrm{E}+04$ \\
\hline T4(valley) & MO-03-47 & 2100 & 4459.636 & 10022.559 & 25.0 & $2.85 \mathrm{E}+05$ & $2.96 \mathrm{E}+04$ \\
\hline $\mathrm{T} 4$ (valley) & MO-03-48 & 2100 & 4459.636 & 10022.559 & 25.0 & $4.02 \mathrm{E}+05$ & $5.17 \mathrm{E}+04$ \\
\hline $\mathrm{T} 4$ (valley) & MO-03-49 & 2100 & 4459.636 & 10022.559 & 25.0 & $2.52 \mathrm{E}+05$ & $8.94 \mathrm{E}+04$ \\
\hline T4(valley) & MO-03-50 & 2100 & 4459.636 & 10022.559 & 25.0 & $1.77 \mathrm{E}+05$ & $3.99 \mathrm{E}+04$ \\
\hline T4(valley) & MO-03-51 (T) & 2100 & 4459.636 & 10022.559 & 25.0 & $1.16 \mathrm{E}+05$ & $2.00 \mathrm{E}+04$ \\
\hline $\mathrm{T} 4$ (valley) & MO-03-55 (B) & 2100 & 4459.636 & 10022.559 & 25.0 & $1.78 \mathrm{E}+05$ & $1.87 \mathrm{E}+04$ \\
\hline $\mathrm{T} 4$ & weighted mean & & & & & $1.89 \mathrm{E}+05$ & $8.88 \mathrm{E}+03$ \\
\hline bedrock T4 & MO05-1 & 2120 & 4459.420 & 10022.610 & 25.9 & $2.12 \mathrm{E}+04$ & $5.33 \mathrm{E}+03$ \\
\hline bedrock T4 & MO05-2 & 2120 & 4459.420 & 10022.610 & 25.9 & $1.98 \mathrm{E}+04$ & $5.33 \mathrm{E}+03$ \\
\hline bedrock T4 & MO05-3 & 2120 & 4459.420 & 10022.610 & 25.9 & $1.12 \mathrm{E}+04$ & $4.26 \mathrm{E}+03$ \\
\hline bedrock T4 & MO05-4 & 2120 & 4459.420 & 10022.610 & 25.9 & $6.85 \mathrm{E}+03$ & $3.43 E+03$ \\
\hline bedrock T4 & weighted mean & & & & & $1.26 E+04$ & $2.18 \mathrm{E}+03$ \\
\hline
\end{tabular}

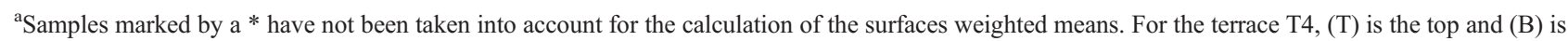
the bottom of the boulders. Production rates have been determined using the parameters of Stone [2000]. Surficial boulders are meter-scale, cobbles in the profiles are decimeter-scale.

The second component appears more clearly at the middle reaches of the drainage basin, where the incision rate is $\sim 0.6 \mathrm{~mm} / \mathrm{yr}$ during the Upper Pleistocene and reaches $\sim 5 \mathrm{~mm} / \mathrm{yr}$ during the Holocene, namely one order of magnitude greater than the rock uplift rate. The growth of the hydrological network appears associated with the pro- gressive horizontal retreat of the plateau. Indeed, considering the N-S length of the Bitut valley (about $10 \mathrm{~km}$ ), the volume of rocks eroded within the valley (order of $10 \mathrm{~km}^{3}$ ), the volume of sediments that form one alluvial fan every climatic pulse (order of $0.1 \mathrm{~km}^{3}$ ), and the age of the massif 


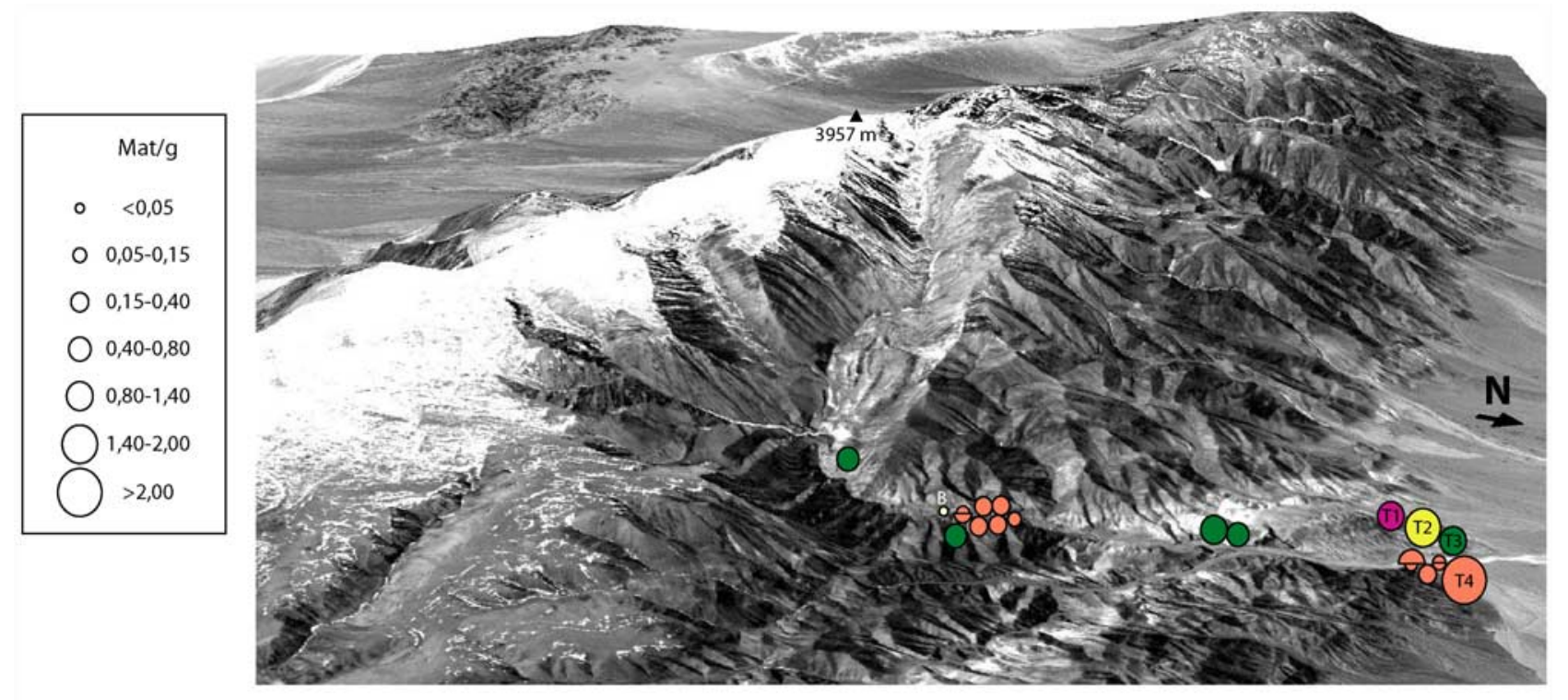

$\mathrm{B}$ : bedrock; T1,T2,T3, T4 : strath terraces

Figure 16. Graphical representation of the distribution of the ${ }^{10} \mathrm{Be}$ concentrations within the Bitut valley. Concentrations of terraces T1, T2 and T3 at the outlet, as well as the concentration of the bedrock profile at the middle reaches of the drainage basin, are weighted means.

(order of $10^{6} \mathrm{Ma}$ ), we can estimate an average retreat of the plateau of $\sim 100 \mathrm{~m}$ every $100 \mathrm{ka}$.

[41] Our results also show that the river incision is not a continuous process but seems rather characterized by strong incision events localized in time, as shown by the $25-\mathrm{m}-$ deep canyon that formed in less than $5 \mathrm{ka}$ at the middle reaches of the Bitut basin. We believe that this feature can be explained by the alternation of the long and dry glacial periods, during which there is no incision, and the short and wet interglacial periods, which are characterized by fluvial adjustment inside the basin. More precisely, our data and the alluvial fans dating within the Gurvan Bogd range by Vassallo et al. [2005] and Ritz et al. [2006] allow us to propose a scenario of the formation/incision/abandonment of the alluvial terraces and fans within the Bitut catchmentpiedmont system during a climatic cycle (Figure 18). At the beginning of the wet period, debris material accumulated on hillslopes during the previous dry period is carried to the drainage network and transported by rivers. This leads to the abrading of the bedrock in the drainage basin and to the erosion of the alluvial apron within the piedmont, and to the formation of the alluvial fans and of the fluvial terraces (15-20 ka, for the last cycle). Then, river incision starts within the piedmont, where alluvial fans are rapidly abandoned, and propagates upstream in the mountain catchment with a lag of several thousand years at the middle reaches of the drainage basin ( $\sim 5 \mathrm{ka}$ for the last cycle). This incision is driven by the massif uplift during the dry period, by the local base level fall at catchment outlet due to fan entrenchment, and by the slope decrease imposed by the drainage growth. The relative magnitude of this last component increases upstream. The canyon carved in the bedrock during this phase is then progressively filled up, essentially by alluvial material re-mobilized from the abandoned terraces. As the river incision, this re-filling phase, which corresponds to the present stage, propagates from the piedmont to the core of the massif.

[42] This evolution has three implications concerning the interpretation of strath terraces as tectonic and climatic markers: 1- The incision measured between abandoned strath terraces always exceeds the rock uplift when catchment is growing and when there is an alluvial apron bordering a mountain, 2- The river response in such a catchment is mostly controlled by drainage growth and piedmont interaction under varying climate than by rock uplift, 3- the river response is characterized by two waves propagating upstream, an incision wave and a re-filling wave.

[43] It is not possible to discuss further the timing between the climatic changes and river response because of the uncertainties on terraces ages. However, data show that terrace abandon is diachronous along the river and takes several thousand years in the Bitut valley. The incision events can be considered instantaneous (order of $10^{3}$ years) at the scale of an interglacial/glacial period (order of $10^{5}$ years). Recent modeling studies have pointed out the delay that may exist between the climatic signal and the incision. This time lag may result from competing vertical and horizontal erosion, itself depending on the evolution of the sediment supply rate [e.g., Hancock and Anderson, 2002], from thresholds in erosion laws [e.g., Tucker and Slingerland, 1997], or from coupling with piedmont [e.g., Poisson and Avouac, 2004; Carretier and Lucazeau, 2005]. In our example, all these factors can play a role. However, 

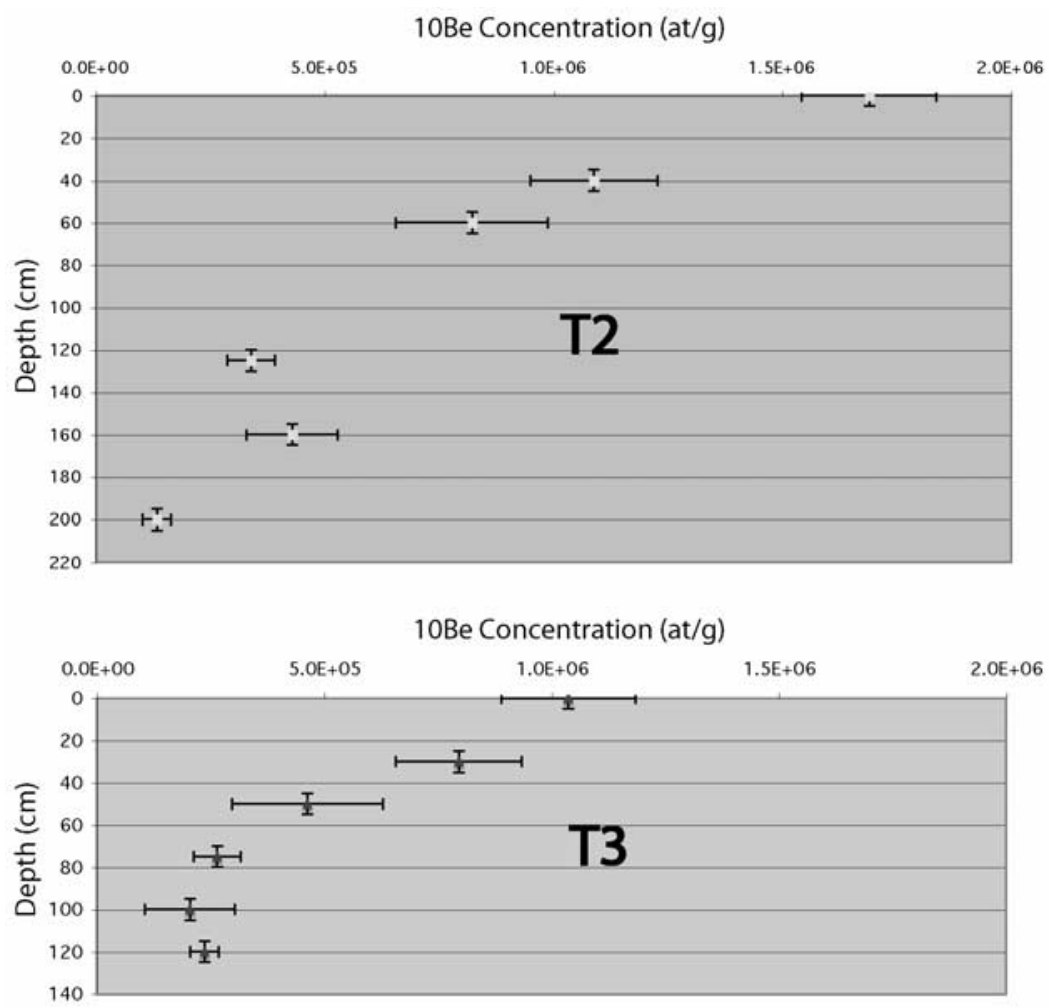

Figure 17. (a) Depth profile of the ${ }^{10} \mathrm{Be}$ distribution within a $2 \mathrm{~m}$ pit-soil in terrace T2. (b) Depth profile of the ${ }^{10} \mathrm{Be}$ distribution within a $1.2 \mathrm{~m}$ pit-soil in terrace T3. Both profiles are situated at the outlet of the Bitut valley.

the strongest factor seems to be the growth of the drainage network, which imposes a decrease of the river gradient, and thus magnifies incision.

\subsection{Tectonic Evolution of Ih Bogd Massif}

[44] The structural and morphological analysis of alluvial markers within the Bitut valley allows us to propose a tectonic model for the evolution of the Ih Bogd massif. The cenozoic faults accommodating the uplift are localized at the limit between different geological terranes, showing that the ongoing deformation reactivates ancient structures. The active faulting progressively migrates outward, on the edges of the relief. We think that this process is related to the distribution of the gravity forces associated to the relief. This allows the massif to widen, which results in a 'staircase' topography. According to the morphology of the northern flank of Ih Bogd, the reverse faulting migrated at least three times in the history of the massif (Figure 4).

Figure 18. Sketch of the evolution of the morphology of the Bitut valley over the Upper Pleistocene - Holocene. (a) Projections of the longitudinal river profile and of the alluvial markers. Vertical axis is not at scale. (b) Corresponding block diagrams of the valley at the middle reaches of the drainage basin. (c) Corresponding block diagrams of the outlet of the drainage basin. (1) At the transition between the penultimate glacial and interglacial periods $(\sim 125-110 \mathrm{ka})$ : enhanced stream power caused by the wetter climate triggers important erosion removing the colluviums that had accumulated within the drainage basin during the previous glacial period. Huge debris-flows, gathering the available sediment load, transport the material within the drainage network abrading the bedrock in the drainage basin, and resulting in the formation of the T3 alluvial terrace inside the massif, and of the F3 fan at the outlet of the valley, which is rapidly abandoned. On figure (a), dotted line represents the following incision and abandonment of the terrace. (2) During the subsequent glacial period $(\sim 110-20 \mathrm{ka})$, the massif is uplifted and is affected by very little river incision, almost localized at the outlet of the valley. At the core of the massif, detrital material accumulates on the slopes and in the drainage network by thermoclastic processes (note that the main incision occurred during the previous interglacial). (3) At the transition between the last glacial and the present interglacial period (20-15 ka), the new climate pulse leads to the formation of the terrace T4 and of the fan F4, which is rapidly abandoned. Note that, at the outlet of the valley, the alluvial fan F4 is set in the alluvial fan F3 even downstream the reverse fault. (4) During the interglacial period, between $\sim 5 \mathrm{ka}$ ago and the present, a strong river incision creates a new canyon and causes the abandonment of the terrace T4. (5) After this incision phase, the canyon is progressively filled up downstream by the present river load. 

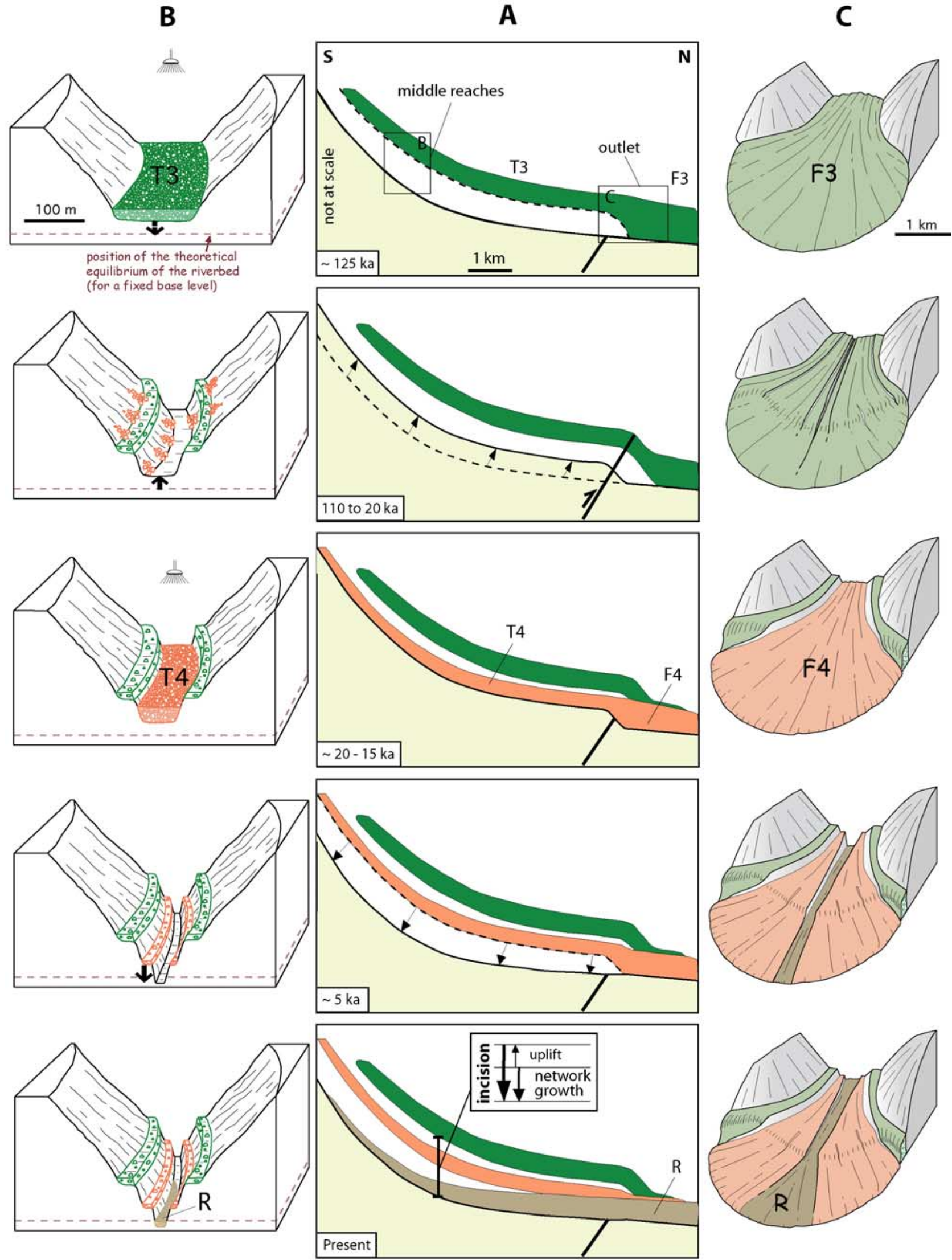

Figure 18

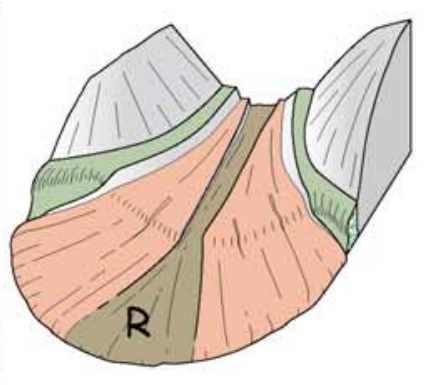



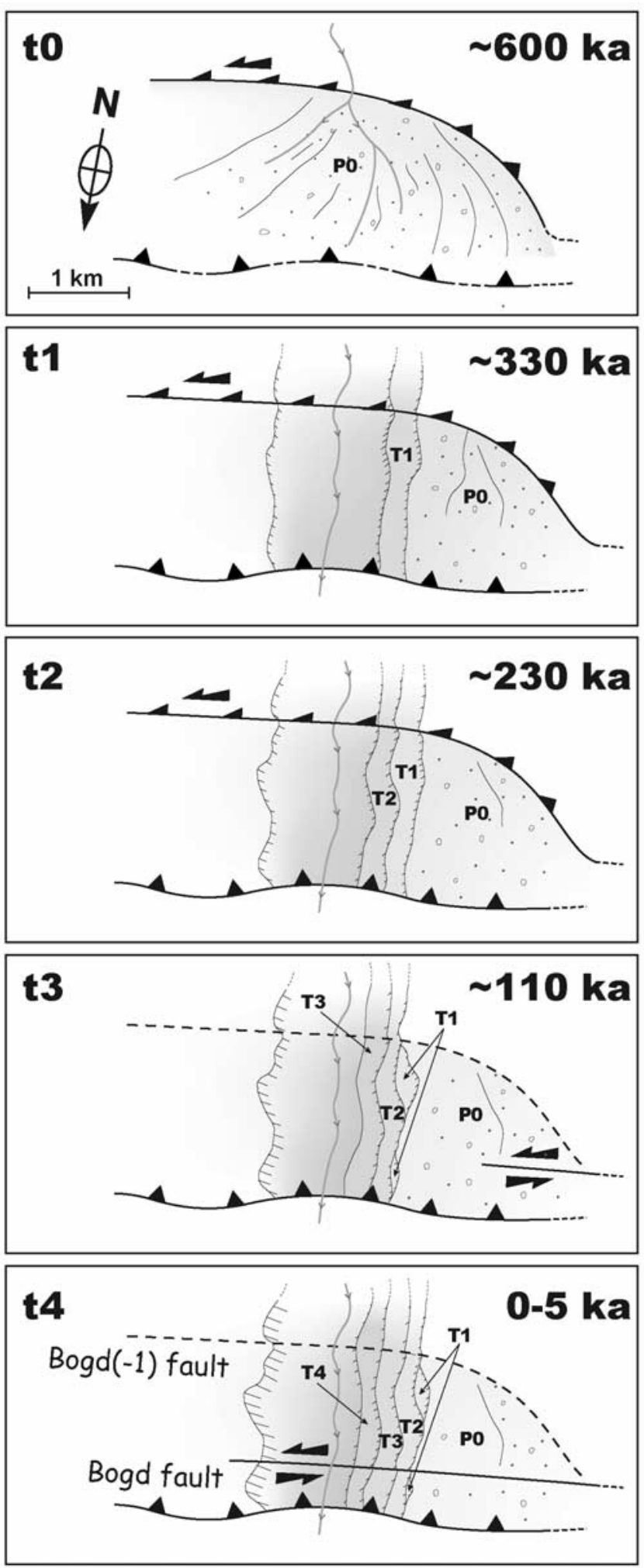

Figure 19. Sketch of the chronology of the evolution of the Bitut valley morphology during the last shift of the active deformation from the $\operatorname{Bogd}(-1)$ to the present Bogd fault.
[45] During the shifting process, the old and the new faults can be both active during a certain period of time. The dating of the terraces in the Bitut valley allow to estimate the duration of the overlapping between the activity of the $\operatorname{Bogd}(-1)$ and the Bogd faults. The Bogd(-1) fault, which displaces the base level of the strath terrace $\mathrm{T} 2$, but does not affect the strath terrace T3, ceased its activity between $\sim 200 \mathrm{ka}$ and $\sim 100 \mathrm{ka}$. The abandonment of P0 marks the beginning of the present frontal thrusting along the Bogd fault. After the height of the surface $\mathrm{P} 0$ with respect of the riverbed, and the incision rate estimated on the last $\sim 200 \mathrm{ka}$ at the same latitude, the abandonment occurred $\sim 600 \mathrm{ka}$ ago. Therefore the shifting process lasted $\sim 400-500 \mathrm{ka}$ (Figure 19). It is difficult to answer whether the massif was uplifting faster when the two faults were moving, since we do not have data enabling to estimate the slip rates of the faults before the Upper Pleistocene. However, the comparison of the Upper Pleistocene uplift rate $(\sim 0.1 \mathrm{~mm} / \mathrm{yr})$ with the Cenozoic uplift rate $(0.25$ and $1 \mathrm{~mm} / \mathrm{yr})$ since the beginning of the uplift (Vassallo et al., 2007) suggests that the massif grew faster during earlier stages of the mountain building process.

[46] As concerns the partitioning of the frontal Bogd fault, or at least the occurrence of the strike-slip fault segment, our morphotectonic data allow estimating the age of the formation of the strike-slip fault segment. Considering the $\sim 3 \mathrm{~m}$ characteristic slip and the total slip of $\sim 20-25 \mathrm{~m}$ suggests that the strike-slip segment formed 20-30 ka ago if we assume an average recurrence time of 3000-5000 years for the Bogd fault as proposed by Ritz et al. [2006]. This is much younger than the activity along the frontal thrust. The activity of the strike-slip segment may be even younger if we assume a recurrence time of $800-$ 2300 years, based on the dating of the penultimate event along the Bogd fault to the East of Ih Bogd massif [Bayasgalan, 1999]. It would yield an age of formation of this strike-slip segment of 5-15 ka. In any case, these results suggest that the frontal Bogd fault has been an oblique fault (reverse and left-lateral) for several hundred thousand years - as was the Bogd(-1) fault - before to partition at the surface very recently.

[47] From the characteristic horizontal offset measured along the strike-slip fault segment, we can infer the horizontal slip rate along this section of the Bogd fault by comparison with what was determined further West, in Noyan Uul. There, the characteristic offset is $5.5 \mathrm{~m}$, and the maximum slip rate is $1.5 \mathrm{~mm} / \mathrm{yr}$ [Ritz et al., 2006]. If we assume that the return period is the same (3000-4000 years), the $3 \mathrm{~m}$ characteristic offset measured within the Bitut area yields a maximum horizontal left-lateral slip rate of $0.8 \mathrm{~mm} / \mathrm{yr}$ along this segment of the Bogd fault.

\section{Conclusion}

[48] Our study shows that the process of incision/abandonment of the alluvial terraces along the Bitut valley integrates the response to the uplift of the Ih Bogd massif as well as the response to the growth of the hydrographic network and the erosion/sedimentation interaction in the 
alluvial apron. From the vertical offset of the alluvial fan that was abandoned during the penultimate interglacial period, we estimate a $\sim 0.1 \mathrm{~mm} / \mathrm{yr}$ Upper Pleistocene Holocene uplift rate of the massif. The incision rate everywhere along the Bitut River is larger than this value, showing that most of the incision is controlled by the growth of the hydrographic network and incision in the alluvial apron. This is particularly obvious at the middle reaches of the drainage basin, where the river incision rate is $\sim 0.6 \mathrm{~mm} / \mathrm{yr}$ during the Upper Pleistocene and $\sim 5 \mathrm{~mm} / \mathrm{yr}$ during the Holocene, which is one order magnitude larger than the uplift rate.

[49] The morphology of the Bitut valley is strongly controlled by the cyclicity of the climate, which is characterized by the alternation of long and dry periods with short and wet periods. After our ${ }^{10} \mathrm{Be}$ dates, we believe that the formation of the alluvial surfaces occurs at the transition between glacial and interglacial periods, when the capacity of the rivers due to increased precipitations allows removing and transporting the sediments accumulated within the basin. This fluvial process, which would be controlled by the global climate changes, is probably related to the aridity of the region. A similar pattern is described in the hot deserts of the American southwest and the Middle East [Bull, 1991].

[50] While the abandonment of the alluvial fans is almost instantaneous, the incision and abandonment of the fluvial terraces propagate upstream and occur several thousand years later. This lag illustrates the time for the river to pass from an aggradational regime to a downcutting regime. This process is probably due to the progressive decrease of the sediment load transported by the river. The incision phase is quickly followed by a new aggradational wave (smaller than the one associated with the beginning of the climatic pulse), also propagating upstream.

[51] The staircase morphology of the massif and the flatness of the summit plateau attest that the uplift of the massif is mainly controlled by reverse faults, and that the active faulting progressively migrates outward, on the edges of the relief. On the northern flank of the Ih Bogd massif, the present frontal fault began to uplift the massif $\sim 600 \mathrm{ka}$ ago, while the previous one ceased its activity between 200 and $100 \mathrm{ka}$ ago. Therefore during the shifting process, the two faults have been both active for a period of $\sim 400-500 \mathrm{ka}$. The lateral growth of the outermost thrust faults (Dalan Turuu foreberg to the North and Gurvan Bulag foreberg to the South) described by Bayasgalan et al. [1999] would therefore correspond to the early stage of a new shift of the deformation in the mountain building process of the Ih Bogd massif.

\section{Appendix A: ANNEXES}

\section{A1. ${ }^{10}$ Be Theory}

[52] Changes of the paleomagnetic field intensity have a significant effect on cosmogenic nuclide production rates at low-latitude sites [Carcaillet et al., 2004] and for exposure ages higher than a few tens of thousand years [Masarik et al., 2001]. Scaling procedure provided by Pigati and Lifton [2004], based on both the geomagnetic intensity modulation and the polar wander, changes the integrated (i.e., intensitycorrected) ${ }^{10} \mathrm{Be}$ production rates by up to $17 \%$. Methods and factors of correction for these paleomagnetic effects remain a matter of debate and uncorrected ages do not significantly differ from intensity-corrected ages, so that interpretation is deliberately based on the uncorrected ages (given in ${ }^{10} \mathrm{Be}-\mathrm{ka}$ ). This approach allows straightforward correction for future refinements in production rates histories and paleomagnetic intensity corrections.

[53] To estimate exposure ages from boulders embedded in alluvial terraces as well as both alluvial surfaces erosion rates and exposure ages from depth profiles, the following equation was used:

$$
\begin{aligned}
C(x, \varepsilon, t)= & C_{i n h} \cdot e^{-\lambda t}+\frac{P_{0} \cdot p_{n}}{\frac{\varepsilon}{\Lambda_{n}}+\lambda} \cdot e^{-\frac{x}{\Lambda_{n}}} \cdot\left[1-e^{-t\left(\frac{\varepsilon}{\Lambda_{n}}+\lambda\right)}\right] \\
& +\frac{\frac{P_{0} \cdot p_{\mu s}}{\varepsilon}+\lambda}{\Lambda_{\mu s}}+e^{-\frac{x}{\Lambda_{\mu s}}} \cdot\left[1-e^{\left.-t\left(\frac{\varepsilon}{\Lambda_{\mu s}}+\lambda\right)\right]}\right. \\
& +\frac{\frac{P_{0} \cdot p_{\mu f}}{\Lambda_{\mu f}}+\lambda}{\Lambda^{-}} \cdot e^{-\frac{x}{\Lambda_{\mu f}}} \cdot\left[1-e^{\left.-t\left(\frac{\varepsilon}{\Lambda_{\mu f}}+\lambda\right)\right]}\right]
\end{aligned}
$$

where $\mathrm{C}(\mathrm{x}, \varepsilon, \mathrm{t})$ is the ${ }^{10} \mathrm{Be}$ concentration function of depth $\mathrm{x}\left(\mathrm{g} / \mathrm{cm}^{2}\right)$, erosion rate $\varepsilon\left(\mathrm{g} / \mathrm{cm}^{2} / \mathrm{yr}\right)$ and exposure time $\mathrm{t}(\mathrm{yr})$; $\Lambda_{\mathrm{n}}, \Lambda_{\mu \mathrm{s}}$, and $\Lambda_{\mu \mathrm{f}}$ are the effective apparent attenuation lengths (in $\mathrm{g} / \mathrm{cm}^{2}$ ), for neutrons, slow muons, and fast muons, respectively; $\mathrm{p}_{\mathrm{n}}, \mathrm{p}_{\mu \mathrm{s}}$ and $\mathrm{p}_{\mu \mathrm{f}}$ are the relative contributions to the ${ }^{10} \mathrm{Be}$ production rate of the three reactions $\left(\mathrm{p}_{\mathrm{n}}+\mathrm{p}_{\mu \mathrm{s}}+\mathrm{p}_{\mu \mathrm{f}}=100 \%\right) ; \mathrm{P}_{0}$ is the production rate at the surface taken from Stone [2000], and $\mathrm{C}_{\mathrm{inh}}$ represents the inherited ${ }^{10} \mathrm{Be}$ concentration potentially acquired by the sample during exposure to cosmic rays prior to emplacement in their sampling position. All calculations were performed using attenuation lengths of 150, 1500, and $5300 \mathrm{~g} / \mathrm{cm}^{2}$ with associated relative contributions to the total surface production rate of $97.85 \%, 1.50 \%$, and $0.65 \%$ for neutrons, slow muons and fast muons, respectively. These values are based on field-calibrated measurements [Braucher et al., 2003]. For the soil profiles, we modeled theoretical curves from the data using the Chi-square inversion procedure described by Ritz et al. [2006], based on the following equation:

$$
\text { Chi }- \text { square }=\sum_{i=1}^{n}\left[\frac{C_{i}-C_{\left(x_{i}, \varepsilon, t\right)}}{\sigma_{i}}\right]^{2}
$$

where $\mathrm{C}_{\mathrm{i}}$ is the measured ${ }^{10} \mathrm{Be}$ concentration at depth $\mathrm{x}_{\mathrm{i}}$, $\mathrm{C}\left(\mathrm{x}_{\mathrm{i}}, \varepsilon, \mathrm{t}\right)$ the theoretical ${ }^{10} \mathrm{Be}$ concentration determined using equation (A1), $\sigma \mathrm{i}$ the analytical uncertainty at depth $\mathrm{x}_{\mathrm{i}}$, and $\mathrm{n}$ is the total number of samples in the profile.

\section{A2. Interpreting ${ }^{10} \mathrm{Be}$ Concentrations in Terms of Pre and Post-depositional Processes}

[54] For each terrace, sampled boulders are generally characterized by similar ${ }^{10} \mathrm{Be}$ concentrations suggesting 


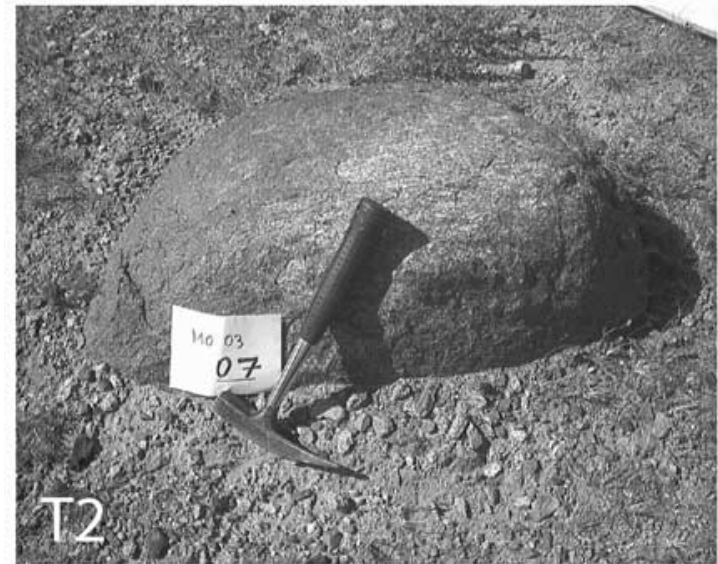

MO03-7: $\mathrm{h}=30 \mathrm{~cm} ; 10 \mathrm{Be}=2.08 \mathrm{Mat} / \mathrm{g}$

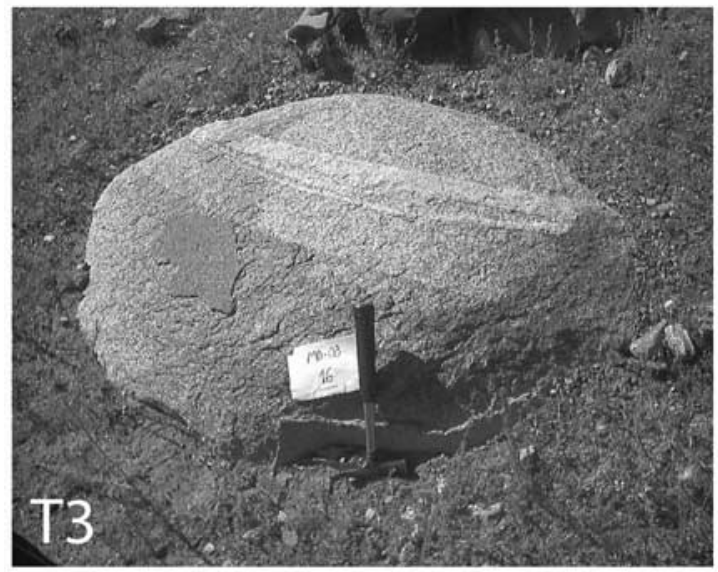

MO03-16: $\mathrm{h}=35 \mathrm{~cm} ; 10 \mathrm{Be}=1.32 \mathrm{Mat} / \mathrm{g}$

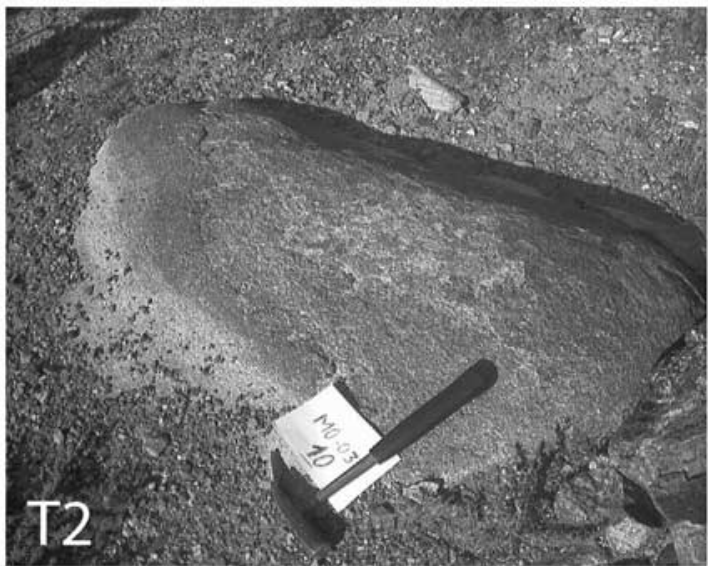

MO03-10: $\mathrm{h}=5 \mathrm{~cm} ; 10 \mathrm{Be}=1.23 \mathrm{Mat} / \mathrm{g}$

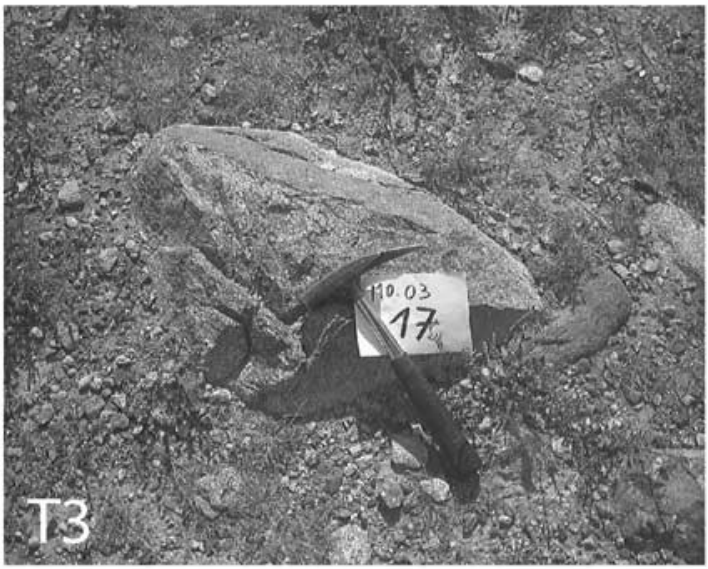

MO03-17: $\mathrm{h}=10 \mathrm{~cm} ; 10 \mathrm{Be}=0.75 \mathrm{Mat} / \mathrm{g}$

Figure A1. Photographs of some boulders sampled within terraces T2 and T3: on the left, typical boulders cropping out largely above the ground surface; on the right, boulders cropping out a few centimeters above the ground surface, characterized by significantly lower ${ }^{10} \mathrm{Be}$ concentrations. $\mathrm{h}=$ difference in height between the top of the boulder and the ground level (photos by R. Vassallo).

common pre-exposure and post-depositional histories. The few exceptions can be explained either by the stochastic processes related to the exhumation and transport of the material within the drainage basins, or by the evolution of their relative position with respect to the top of the surface after deposit. The highest concentrated sample of T4 has probably been exposed for a long time on the slopes of the higher part of Bitut valley or on the summit plateau before reaching the drainage basin and being transported to the outlet by the river. On the contrary, the three less concentrated outliers of the terraces T2 and T3 are only a few centimeters above the ground surface (Figure A1). We can suppose that they have been buried longer than those cropping out $30-40 \mathrm{~cm}$ above the surface, before being "exhumed" by the erosion of the matrix. This interpretation is also supported by the fact that cobbles sampled at the top of the vertical profiles are less concentrated than boulders cropping out well above the ground surface, which suggest that they were exposed to the surface more recently.

[55] Another parameter that strongly influences the ${ }^{10} \mathrm{Be}$ concentration of the alluvial terraces is the geometry of the top of the surfaces. Indeed, terrace T1 with respect to younger terraces T2 and T3, and the remnants of T3 along Bitut valley with respect to the same surface at the outlet, present a priori anomalous low concentrations (Table 1 and Figure 16). These surfaces are characterized by steeper top surfaces with respect to those that are morphologically younger or of the same age, suggesting that they are more eroded. The exhumation of deep boulders is more rapid, and the residence periods at the surface of these boulders, which are also more rapidly evacuated, are shorter. 
[56] Acknowledgments. This study has been funded by the 'Reliefs' INSU-CNRS program, by the Laboratory Géosciences Montpellier, and by the CEREGE of Aix-en-Provence. We are thankful to A. Bayasgalan for fruitful discussions, and D. Javkhlandbold and Baianaa for their help in fieldwork. Many thanks to Anne Delplanque for helping in drawings. The thorough reviews of W. B. Bull and R. Walker allowed us to considerably improve the manuscript. We acknowledge AirFrance for granting the transport of extra-weight scientific material.

\section{References}

Anderson, R. S., J. L. Repka, and G. S. Dick (1996), Explicit treatment of inheritance in dating depositional surfaces using in situ ${ }^{10} \mathrm{Be}$ and ${ }^{26} \mathrm{Al}$, Geology, $24,47-51$.

Baljinnyam, I., A. Bayasgalan, B. A. Borisov, A. Cisternas, M. G. Dem'yanovich, L. Ganbaatar, V. M. Kochetkov, R. A. Kurushin, P. Molnar, H. Philip, and Yu. Ya. Vashchilov (1993), Ruptures of major earthquakes and active deformation in Mongolia and its surroundings, Geol. Soc. Am. Memoir, Memoir 181.

Bayasgalan, A. (1999), Active Tectonics of Mongolia, $\mathrm{PhD}$ thesis, Univ. of Cambridge, Cambridge, $182 \mathrm{pp}$.

Bayasgalan, A., J. Jackson, J.-F. Ritz, and S. Carretier (1999), 'Forebergs', flowers structures, and the development of large intra-continental strike-slip fault: the Gurvan Bogd fault system in Mongolia, J. Struct. Geol., 21, 1285-1302.

Bierman, P. R. (1994), Using in situ produced cosmogenic isotopes to estimate rates of landscape evolution: A review from the geomorphic perspective, J. Geophys. Res., 99, 13,885-13,896.

Braucher, R., E. T. Brown, D. L. Bourlès, and F. Colin (2003), In situ produced ${ }^{10} \mathrm{Be}$ measurements at great depths: implications for production rates by fast muons, Earth Planet. Sci. Lett., 211, 251-258.

Brook, E. J., M. D. Kurz, G. H. Denton, and R. P. Ackert Jr. (1993), Chronology of Taylor Glacier Advances in Arena Valley, Antarctica, Using in Situ Cosmogenic ${ }^{3} \mathrm{He}$ and ${ }^{10} \mathrm{Be}$, Quaternary Res., 39, $11-23$.

Brown, E. T., J. M. Edmond, G. M. Raisbeck, F. Yiou, M. D. Kurz, and E. J. Brook (1991), Examination of surface exposure ages of Antarctic moraines using in situ produced ${ }^{10} \mathrm{Be}$ and ${ }^{26} \mathrm{Al}$, Geochim. Cosmochim. Acta, 55, 2699-2703.

Bull, W. B. (1991), Geomorphic responses to climatic change, Oxford Univ. Press, New York, $326 \mathrm{pp}$

Carcaillet, J., D. L. Bourlès, and N. Thouveny (2004), Geomagnetic dipole moment and ${ }^{10} \mathrm{Be}$ production rate intercalibration from authigenic ${ }^{10} \mathrm{Be} /{ }^{9} \mathrm{Be}$ for the last 1.3 Ma, Geochem. Geophys. Geosyst. 5(5), Q05006, doi:10.1029/2003GC000641.

Carretier, S. (2000), Cycle sismique et surrection de la chaîne de Gurvan Bogd (Mongolie). Approche de la géomorphologie quantitative, $\mathrm{PhD}$ thesis, Université de Montpellier 2, $324 \mathrm{pp}$.

Carretier, S., and F. Lucazeau (2005), How does alluvial sedimentation at range fronts modify the erosional dynamics of mountain catchments?, Basin Res., 17, 361-381, doi:10.1111/j.1365-2117.2005.00270.x.

Carretier, S., F. Lucazeau, and J. F. Ritz (1998), Approche numérique des intéractions entre climat, faille active et érosion, C. R. Acad. Sci. Paris, 326, 391-397.

Carretier, S., J. F. Ritz, J. Jackson, and A. Bayasgalan (2002), Morphological dating of cumulative reverse fault scarp: Examples from the Gurvan Bogd fault system, Mongolia, Geophys. J. Int., 148, $256-277$.

Cunningham, D. (2006), Structural and topographic characteristics of restraining bend mountain ranges in the Altai, Gobi Altai and easternmost Tien Shan, European Geosciences Union, Vienna, SRef-ID: 1607-7962/gra/EGU06-A-01888.

Cunningham, D., S. Davies, and G. Badarch (2003), Crustal architecture and active growth of the Sutai Range, western Mongolia: A major intracontinental, intraplate restraining bend, J. Geodyn., 36, $169-191$.
Dunne, J., D. Elmore, and P. Muzikar (1999), Scaling factors for the rates of production of cosmogenic nuclides for geometric shielding and attenuation at depth on sloped surfaces, Geomorphology, 27, 3 11.

Florensov, N. A., and V. P. Solonenko (Eds.) (1965), The Gobi-Altay Earthquake, U.S. Dep. of Commer, Washington, D. C

Gosse, J. C., and F. M. Phillips (2001), Terrestrial in situ cosmogenic nuclides: Theory and application, Quaternary Sci. Rev., 20, 1475-1560.

Hancock, G. S., and R. S. Anderson (2002), Numerical modeling of fluvial strath-terrace formation in response to oscillating climate, GSA Bulletin, 114(9), $1131-1142$.

Hanks, T., J.-F. Ritz, K. Kendrick, R. C. Finkel, and C. D. Garvin (1997), Uplift rates in a continenta interior: faulting offsets of a $\sim 100 \mathrm{Ka}$ abandoned fan along the Bogd fault, southern Mongolia, Proceedings of the Pensose Conference on the Tectonics of Continental Interiors.

Jackson, J., J.-F. Ritz, L. Siame, G. Raisbeck, F. Yiou, R. Norris, J. Youngson, and E. Bennett (2002), Fault growth and landscape development rates in Otago, New Zealand, using in situ cosmogenic ${ }^{10}$ Be, Earth Planet. Sci. Lett., 195, 185-193.

Kurushin, R. A., A. Bayasgalan, M. Ölziybat, B. Enkhtuvshin, P. Molnar, C. Bayarsayhan, K. W. Hudnut, and J. Lin (1997), The surface rupture of the 1957 Gobi-Altay, Mongolia, earthquake, Geol. Soc. Am. Spec. Pap., vol. 320 .

Lal, D. (1991), Cosmic ray labeling of erosion surfaces: in situ nuclide production rates and erosion models, Earth Planet. Sci. Lett., 104, 424-439.

Masarik, J., M. Frank, J. M. Schäfer, and R. Wieler (2001), Correction of in situ cosmogenic nuclide production rates for geomagnetic field intensity variations during the past 800000 years, Geochim Cosmochim. Acta, 65(3-4), 515-521.

Molnar, P., and D. Qidong (1984), Faulting associated with large earthquakes and the average rate of deformation in central and eastern Asia, J. Geophys. Res., 89, 6203-6227.

Pigati, J. S., and N. A. Lifton (2004), Geomagnetic effects on time-integrated cosmogenic nuclide production with emphasis on in situ ${ }^{14} \mathrm{C}$ and ${ }^{10} \mathrm{Be}$ Earth Planet. Sci. Lett., 226(1-2), 193-205.

Poisson, B., and J.-P. Avouac (2004), Holocene Hydrological Changes Inferred from Alluvial Stream Entrenchment in North Tian Shan (Northwestern China), J. Geol., 112, 231-249.

Prentice, C., K. Kendrick, K. Berryman, A. Bayasgalan, J. F. Ritz, and J. Q. Spencer (2002), Prehistoric ruptures of the Gurvan Bulag fault, Gobi Altay, Mongolia, J. Geophys. Res., 107(B12), 2321, doi:10.1029/2001JB000803.

Raisbeck, G. M., F. Yiou, D. L. Bourlès, J. Lestringuez, and D. Deboffe (1987), Measurements of ${ }^{10} \mathrm{Be}$ and ${ }^{26} \mathrm{Al}$ with a Tandetron AMS facility, Nucl. Instr. Methods, 29, 22-26.

Ritz, J.-F., E. T. Brown, D. L. Bourlès, H. Philip, A. Schlupp, G. M. Raisbeck, F. Yiou, and B. Enkhtuvshin (1995), Slip rates along active faults estimated with cosmic-ray-exposure dates: Application to the Bogd fault, Gobi-Altaï, Mongolia, Geology, 23, 1019-1022.

Ritz, J.-F., D. Bourlès, E. T. Brown, S. Carretier, J. Chery, B. Enhtuvushin, P. Galsan, R. C. Finkel, T. C. Hanks, K. J. Kendrick, H. Philip, G. Raisbeck, A. Schlupp, D. P. Schwartz, and F. Yiou (2003), Late Pleistocene to Holocene slip rates for the Gurvan Bulag thrust fault (Gobi-Altay, Mongolia) estimated with ${ }^{10} \mathrm{Be}$ dates, J. Geophys. Res., 108(B3), 2162, doi:10.1029/ 2001JB000553.

Ritz, J.-F., R. Vassallo, R. Braucher, E. Brown, S. Carretier, and D. L. Bourlès (2006), Using In Situ-Produced ${ }^{10}$ Be to Quantify Active Tectonics in the Gurvan Bogd Mountain Range (Gobi-Altay, Mongolia), in Geological Soc. of America Special Paper 415 "In Situ-Produced Cosmogenic Nuclides and Quantification of Geological Processes", edited by L. Siame, D. L. Bourlès, and E. T. Brown, pp. 87-110.

Siame, L., R. Braucher, and D. Bourlès (2000), Les nucléides cosmogéniques produits in situ: de nouveaux outils en géomorphologie quantitative, Bull. Soc. Geol. Fr. 171, 383-396.

Siame, L., O. Bellier, R. Braucher, M. Sébrier, M. Cushing, D. Bourlès, B. Hamelin, E. Baroux, B. de Voogd, G. Raisbeck, and F. Yiou (2004), Local erosion rates versus active tectonics: Cosmic ray exposure modelling in Provence (south-east France), Earth Planet. Sci. Lett., 7010, 1-21.

Schwartz, D., and K. Coppersmith (1984), Fault behavior and characteristic earthquakes: Examples from the Wasatch and San Andreas faults, J. Geophys. Res., 89, 5681-5698.

Stone, J. O. (2000), Air pressure and cosmogenic isotope production, J. Geophys. Res., 105(B10), 23,75313,759 .

Tucker, G. E., and R. Slingerland (1997), Drainage basin responses to climate change, Water Resour. Res., 33(8), 2031-2047.

Vassallo, R., J.-F. Ritz, R. Braucher, and S. Carretier (2005), Dating faulted alluvial fans with cosmogenic ${ }^{10} \mathrm{Be}$ in the Gurvan Bogd mountain (Gobi-Altay, Mongolia): Climatic and tectonic implications, Terra Nova, 17, 278-285, doi:10.1111/j.13653121.2005.00612.x

Vassallo, R., M. Jolivet, J.-F. Ritz, R. Braucher, C. Larroque, C. Sue, M. Todbileg, and D. Javkhlanbold (2007), Uplift age and rates of the Gurvan Bogd system (Gobi-Altay) by apatite fission track analysis, Earth Planet. Sci. Lett., 259(3-4), 333-346, doi:10.1016 j.eps1.2007.04.047.

Walker, R. T., A. Bayasgalan, R. Carson, R. Hazlett, L. McCarthy, J. Mischler, E. Molor, P. Sarantsetseg, L. Smith, B. Tsogtbadrakh, and G. Tsolmon (2006), Geomorphology and structure of the Jid right-lateral strike-slip fault in the Mongolian Altay mountains, J. Struct. Geol., 28(9), 1607-1622.

Woodcock, N. H., and M. Fischer (1986), Strike-slip duplexes, J. Struct. Geol., 8(7), 725-735.

A. Arzhannikova and S. Arzhannikov, Institut of Earth Crust, Irkutsk, Russia.

D. Bourlès and R. Braucher, CEREGE, Aix-enProvence, UMR 6635, France.

S. Carretier, LMTG, Toulouse, UMR 5563, France.

A. Chauvet, M. Jolivet, J.-F. Ritz, and R. Vassallo, Laboratoire Géosciences Montpellier, Université Montpellier II, UMR CNRS/UM2 5243, France. (vassallo@ geoazur.com)

C. Larroque, Géosciences Azur, Sophia-Antipolis, Valbonne, UMR 6526, France.

C. Sue, Département de Géologie, Université de Neuchatel, Suisse.

M. Todbileg, Mongolian University of Science and Technology, Ulaan Baatar, Mongolia. 